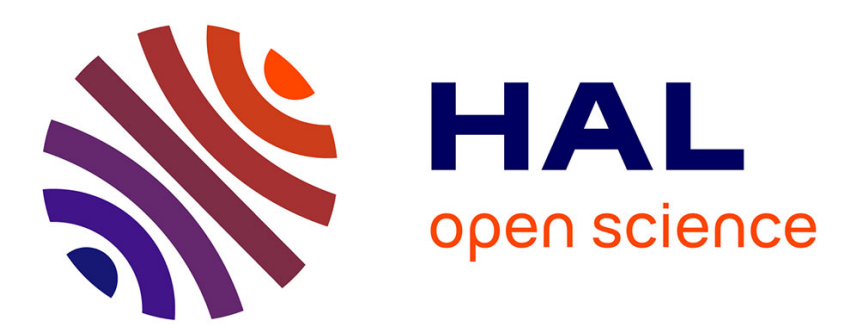

\title{
Novel substituted N-benzyl(oxotriazinoindole) inhibitors of aldose reductase exploiting ALR2 unoccupied interactive pocket
}

Matúš Hlaváč, Lucia Kováčiková, Marta Šoltésová Prnová, Gabriela Addová, Gilles Hanquet, Milan Štefek, Andrej Boháč

\section{To cite this version:}

Matúš Hlaváč, Lucia Kováčiková, Marta Šoltésová Prnová, Gabriela Addová, Gilles Hanquet, et al.. Novel substituted N-benzyl(oxotriazinoindole) inhibitors of aldose reductase exploiting ALR2 unoccupied interactive pocket. Bioorganic and Medicinal Chemistry, 2020. hal-03070904

\section{HAL Id: hal-03070904 https://hal.science/hal-03070904}

Submitted on 16 Dec 2020

HAL is a multi-disciplinary open access archive for the deposit and dissemination of scientific research documents, whether they are published or not. The documents may come from teaching and research institutions in France or abroad, or from public or private research centers.
L'archive ouverte pluridisciplinaire HAL, est destinée au dépôt et à la diffusion de documents scientifiques de niveau recherche, publiés ou non, émanant des établissements d'enseignement et de recherche français ou étrangers, des laboratoires publics ou privés. 


\title{
Novel substituted $N$-benzyl(oxotriazinoindole) inhibitors of aldose reductase exploiting ALR2 unoccupied interactive pocket
}

\author{
Matúš Hlaváč ${ }^{*}$, Lucia Kováčiková2, Marta Šoltésová Prnováa ${ }^{2}$ Gabriela Addová ${ }^{1}$, Gilles \\ Hanquet $^{3}$, Milan Štefek ${ }^{2}$, Andrej Boháč $\check{c}^{1,4}$ \\ ${ }^{1}$ Department of Organic Chemistry, Faculty of Natural Sciences, Comenius University in Bratislava, Ilkovičova \\ 6, 84215 Bratislava, Slovakia \\ ${ }^{2}$ Institute of Experimental Pharmacology and Toxicology, CEM, SAS, Dúbravská cesta 9, 84104 Bratislava, \\ Slovakia \\ ${ }^{3}$ Université de Strasbourg, Université de Haute-Alsace, CNRS, UMR 7042-LIMA, ECPM, 25 rue Becquerel, \\ 67087 Strasbourg, France \\ ${ }^{4}$ Biomagi, Ltd., Mamateyova 26, 85104 Bratislava, Slovakia, biomagibiomagi@gmail.com \\ * corresponding author: E-mail: hlavac.matus91@gmail.com
}

\begin{abstract}
Recently we have developed novel oxotriazinoindole inhibitors (OTIs) of aldose reductase (ALR2), characterized by high efficacy and selectivity. Herein we describe novel OTI derivatives design of which is based on implementation of additional intermolecular interactions within an unoccupied pocket of the ALR2 enzyme. Four novel derivatives, OTI(7-10), of the previously developed $N$-benzyl(oxotriazinoindole) inhibitor OTI-6 were synthetized and screened. All of them revealed 2 to 6 times higher ALR2 inhibitory efficacy when compared to their non-substituted lead compound OTI-6. Moreover, the most efficient ALR2 inhibitor OTI-7 $\left(\mathrm{IC}_{50}=76 \mathrm{nM}\right)$ possesses remarkably high inhibition selectivity $\left(\mathrm{S}_{\mathrm{F}} \geq\right.$ 1300 ) in relation to structurally related aldehyde reductase (ALR1). Derivatives OTI-(8-10) bearing the substituents $-\mathrm{CONH}_{2},-\mathrm{COOH}$ and $-\mathrm{CH}_{2} \mathrm{OH}$, possess 2-3 times lower inhibitory efficacy compared to OTI-7, but better than the reference inhibitor OTI-6. Desolvation penalty is suggested as a possible factor responsible for the drop in ALR2 inhibitory efficacy observed for derivatives OTI-(8-10) in comparison to OTI-7.
\end{abstract}

Keywords: aldose reductase (ALR2); interactive pocket; $N$-benzyl(oxotriazinoindole) ALR2 inhibitors; desolvation penalty 


\section{Introduction}

Diabetes mellitus (DM), a wide-spread human disorder, has been recognized as a main cause of health problems such as blindness, neuronal diseases, hearth and kidney failures. ${ }^{1}$ One of the most important therapeutic targets, implicated in late diabetic complications, is the polyol pathway. This pathway involves two steps, where $D$-glucose is converted to $D$-fructose via $D$ sorbitol. (Fig. 1) In the first step, aldose reductase (ALR2) catalyses reduction of $D$-glucose to $D$-sorbitol while NADPH is oxidized to $\mathrm{NADP}^{+}{ }^{2}$ Deficiency of NADPH hampers regeneration of glutathione (GSH) from its dimer (GSSG), causing high excess of intracellular reactive oxygen species (ROS) in various tissues including the heart, neurons, eyes and kidneys. $^{3}$ In addition, high concentration of highly polar $D$-sorbitol results in osmotic imbalances and cell swelling. ${ }^{4} D$-Fructose, formed in the second step of the polyol pathway, causes excessive glycation of proteins and lipids and enhances formation of advanced glycation and lipoxidation end products (AGEs and ALEs), also involved in inflammation and oxidative stress. According to all these facts, inhibition of ALR2 activity can indirectly suppress above mentioned pathological imbalances and slow down late diabetic complications.

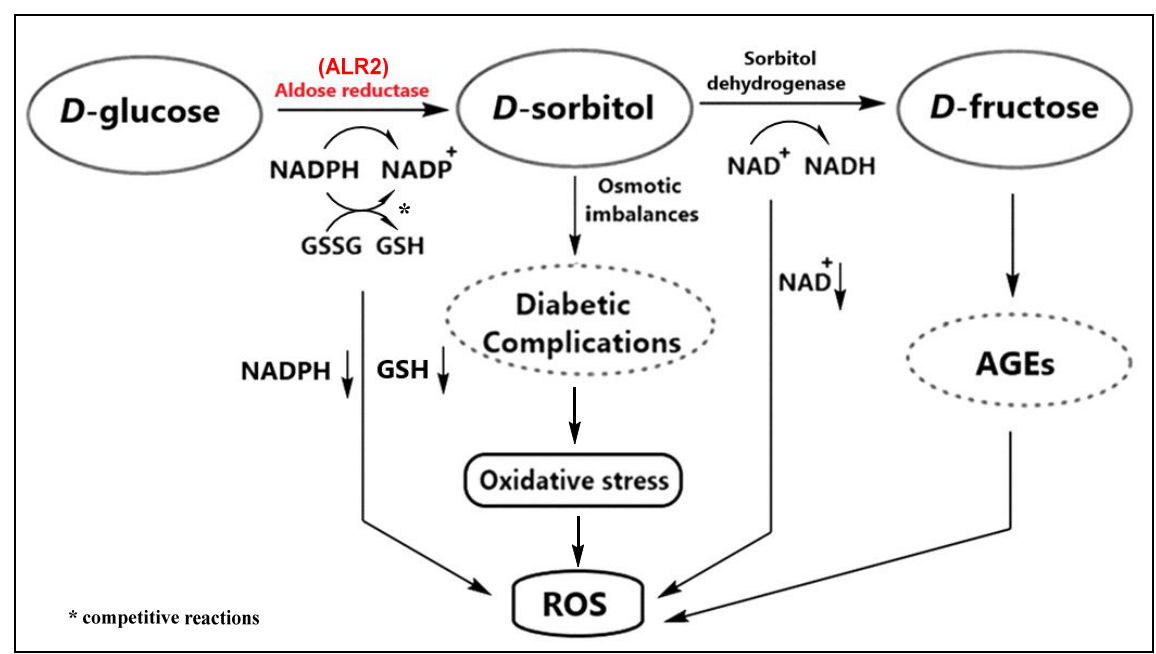

Figure 1. An illustration of the polyol pathway and its implication in the diabetic complications.

Reduction of the carbonyl functional group of lipid peroxidation products, namely 4hydroxynonenal (HNE), and its glutathione adduct (GS-HNE) by ALR2 may generate intermediates contributing to activation of pro-inflammatory signaling. It points to aldose reductase inhibitors (ARIs) as promising agents in therapy of chronic inflammatory disorders and even several types of tumors related to chronic inflammation. ${ }^{5-9}$ Moreover, interventions 
with ARIs may have potential in attenuation of pathological consequences of several genetic metabolic disorders including galactosemia and sorbitol dehydrogenase deficiency. ${ }^{10}$

Over the last 40 years, numerous ARIs have been developed, but only epalrestat as ARI is therapeutically available in Japan, China and India. ${ }^{11}$ Most of structurally different ARIs have been refused in clinical trials mainly for their low in vivo efficacies, pharmacokinetic drawbacks and/or side effects. The largest class of ARIs are carboxylic acids where carboxylate anion moiety occupies an anion binding pocket of the active site of ALR2. Štefek et al. developed the carboxymethylated thioxotriazinoindole cemtirestat (CMTI), 2-(3thioxo-2H-[1,2,4]triazino[5,6- $b]$ indol-5(3H)-yl)acetic acid, as a novel lead-like candidate with excellent ALR2 inhibitory efficacy, selectivity and antioxidant activity. ${ }^{12}$ Very recently, the inhibition efficacy and selectivity of CMTI was improved by isosteric replacement of sulphur with oxygen, which led to the discovery of the oxotriazinoindole inhibitor OTI, 2-(3-oxo- $2 \mathrm{H}$ $[1,2,4]$ triazino[5,6-b]indol-5(3H)-yl)acetic acid, with markedly increased inhibition selectivity. ${ }^{13}$ In this study, we aimed to exploit a previously unoccupied ALR2 pocket consisting of Trp219, Ala299 and Leu301 (PDB: 4QX4). In order to utilize this pocket to ensure additional interactions novel $N$-benzyl(oxotriazinoindole) derivatives were proposed. Besides the leading unsubstituted $N$-benzyl derivative OTI-6 previously described by us, ${ }^{13}$ herein we proposed, synthesized and screened its substituted derivatives OTI-(7-10), containing different functional groups in an ortho position on a benzyl aromatic ring. (Scheme 1)

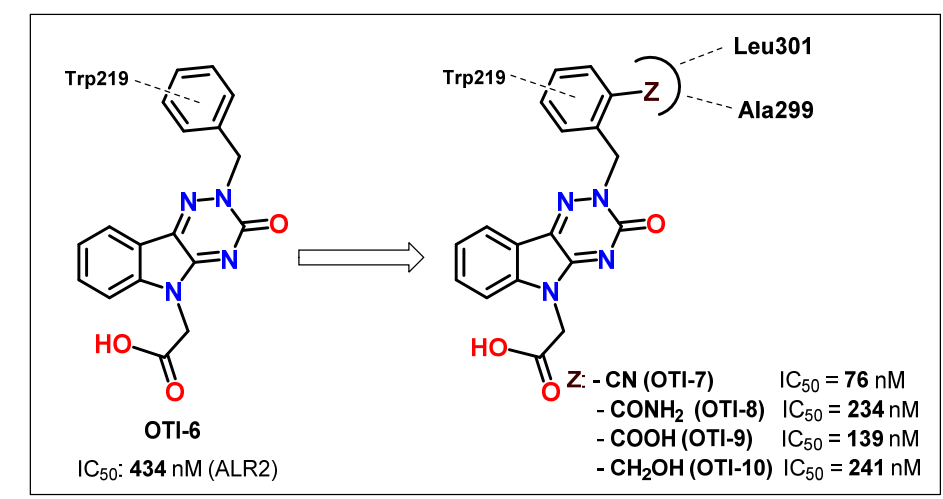

Scheme 1. Design of novel benzyl derivatives OTI-(7-10) from OTI-6.

\section{Results and discussion}

In this study, we aimed to explore an unoccupied ALR2 pocket in close proximity to the triazine ring of CMTI inhibitor (PDB: 4QX4). This pocket contains important amino acid residues e.g. Trp219, Ala299 and Leu301. In order to utilize this pocket for additional ligand- 
enzyme interactions, novel $N$-benzyl(oxotriazinoindole) derivatives OTI-(7-10) have been designed and developed.

\section{Predictions and interaction diagrams of OTI-(7-10)}

Proposed derivatives OTI-(7-10) have been docked into the ALR2 protein conformer taken from the complex PDB: 4QX4. As expected, proposed derivatives possess additional H-bonds in the ALR2 unoccupied lipophilic pocket with Ala299 or Leu301 from backbone and two $\pi-\pi$ interactions of OTI's benzyl moiety with Trp219. Furthermore, the other important interactions e.g. of an acetate group in an anion binding pocket are crucial for a high ALR2 activity of all OTI derivatives (ionic interactions: with His110 and Lys77 and H-bonds with His110, Tyr48 and Trp111). Predicted interactions of OTI-(7-10) inhibitors are depicted in the diagrams (Fig. 2) as well as in the Supporting information of this paper.

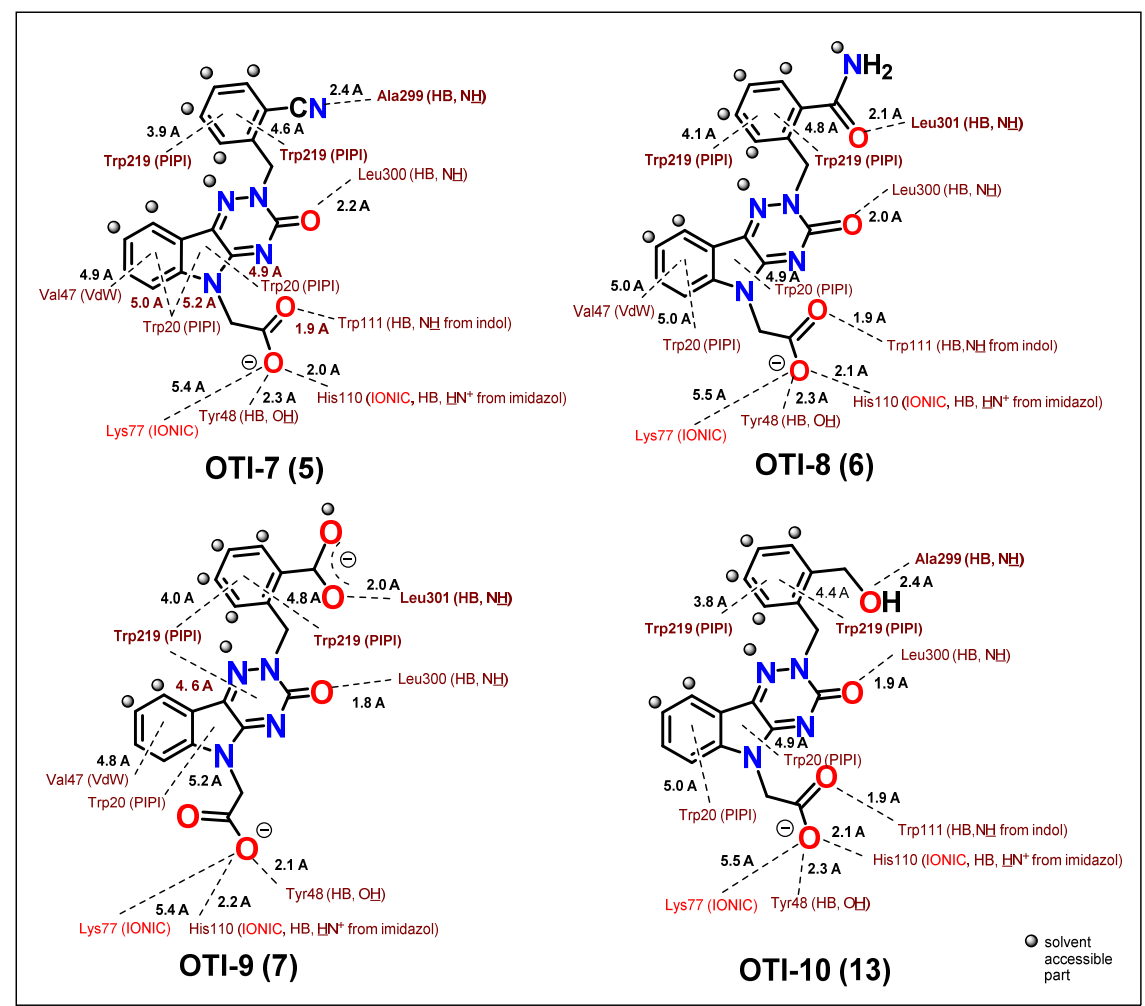

Figure 2. Predicted OTI-(7-10) interactions in a binding site of ALR2 enzyme (PDB: 4QX4).

\section{Synthesis of OTI-(7-10)}

Compound 1 (OTI $)^{13}$ represented a joint starting material for synthesis of all proposed inhibitors OTI-(7-10). In the first step, OTI underwent acidic esterification by EtOH (abs) in 
the presence of cat. amount of $\mathrm{H}_{2} \mathrm{SO}_{4}$ (conc). Obtained ester 2 was alkylated to 4 by $\mathrm{CaH}_{2}$ in DMF, followed by addition of 2-(bromomethyl)benzonitrile 3 at $80{ }^{\circ} \mathrm{C}$. Obtained $\mathrm{N}$-(2cyanobenzyl) derivative 4 was used as an intermediate for the synthesis of all proposed compounds OTI-(7-9). Hydrolysis of an ester group of $\mathbf{4}$ by aq solution of $\mathrm{NaOH}$ in a mixture of $\mathrm{MeOH} / \mathrm{H}_{2} \mathrm{O}(1 / 1)$ at reflux within 30 min provided the $N$-(2-cyanobenzyl)acetate OTI-7. Partial hydrolysis of $\mathrm{N}$-(2-cyanobenzyl)ester 4 with TFA / $\mathrm{H}_{2} \mathrm{SO}_{4}$ (conc) (4/1) at $70{ }^{\circ} \mathrm{C}$ within $6 \mathrm{~h}$ afforded $N$-(2-carbamoylbenzy)acetate OTI-8. Biscarboxylic acid OTI-9 was prepared by complete hydrolysis of 4 in a mixture of $\mathrm{H}_{2} \mathrm{O} / \mathrm{H}_{2} \mathrm{SO}_{4}$ (conc) $(1 / 1)$ at $100{ }^{\circ} \mathrm{C}$ within 8 days. (Scheme 2)

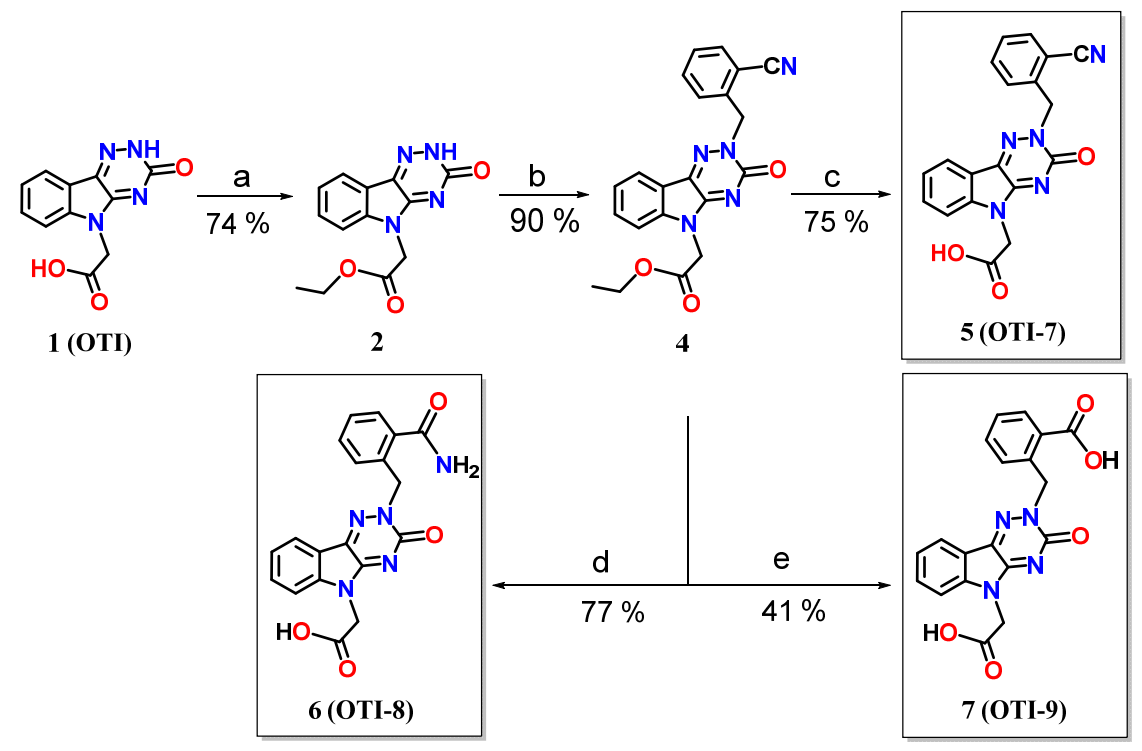

Scheme 2. Preparation of OTI-(7-9) from OTI.

Reagents and conditions: (a) EtOH (abs), cat $\mathrm{H}_{2} \mathrm{SO}_{4}$ (conc), reflux, $6 \mathrm{~h}$; (b) (1) $\mathrm{CaH}_{2}$ (1.19 mol eq), DMF (abs), $80^{\circ} \mathrm{C}, 30 \mathrm{~min}$, (2) 2-(bromomethyl)benzonitrile (3) (1.19 mol eq), from rt to $80^{\circ} \mathrm{C}, 1 \mathrm{~h}$; (c) $\mathrm{NaOH}(2.00 \mathrm{~mol} \mathrm{eq})$, $\mathrm{MeOH} / \mathrm{H}_{2} \mathrm{O}$ (1 / 1) reflux, 30 min; (d) TFA / $\mathrm{H}_{2} \mathrm{SO}_{4}$ (conc) (4 / 1), $70{ }^{\circ} \mathrm{C}, 6 \mathrm{~h}$; (e) $\mathrm{H}_{2} \mathrm{O} / \mathrm{H}_{2} \mathrm{SO}_{4}$ (conc) (1 / 1), $100^{\circ} \mathrm{C}, 8 \mathrm{~d}$.

Synthesis of hydroxymethyl derivative OTI-10 required THP protected (bromomethyl)phenylmethanol 11, which was prepared in three steps starting from phthalic anhydride (8). Compound 8 was reduced to diol 9 by $\mathrm{LiAlH}_{4}$ in THF (abs) at $0{ }^{\circ} \mathrm{C}$ to $\mathrm{rt}$ for 16 $\mathrm{h}$ in $94 \%$ yield. Afterwards, treatment of diol 9 by conc $\mathrm{HBr}(48 \%)$ in toluene at $70{ }^{\circ} \mathrm{C}$ within 20 min provided product $\mathbf{1 0}$ and traces of bis-brominated side product. After FLC separation, required compound $\mathbf{1 0}$ was obtained in $56 \%$ yield. Finally, $O$-protected compound 11 was obtained in $89 \%$ yield by reaction of 3,4-dihydropyrane (DHP) in a presence of cat amount of pyridinium $p$-toulenesulfonate (PPTS) in refluxing DCM within 30 
min. Afterwards, previously prepared ester 2 was alkylated with 11 by $\mathrm{CaH}_{2}$ in $\mathrm{DMF}$ at $80{ }^{\circ} \mathrm{C}$ within 30 min to perform an intermediate 12. Compound 12 was hydrolysed to desired $N$-(2hydroxymethylbenzyl) derivative OTI-10 by aq $\mathrm{HCl}$ in dioxane at $90{ }^{\circ} \mathrm{C}$ within $8 \mathrm{~h}$ in $66 \%$ yield. (Scheme 3)

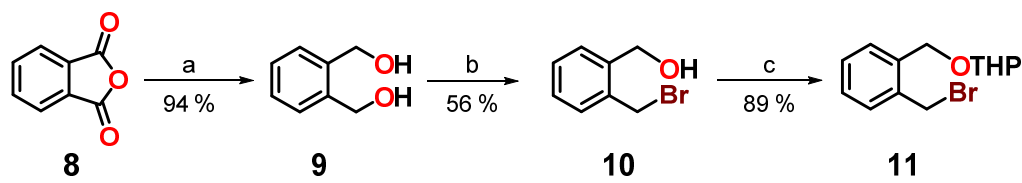

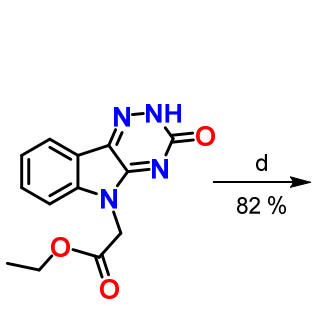

2

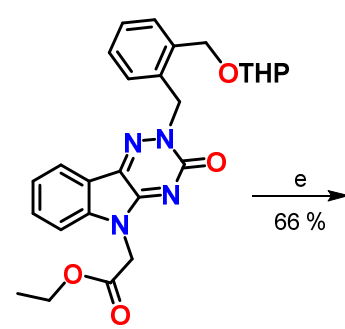

12

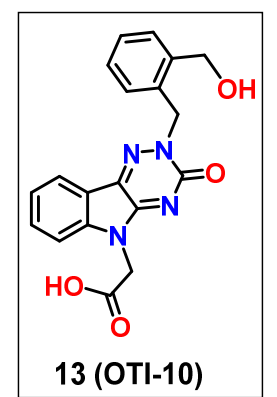

$13($ OTI-10)

Scheme 3. Preparation of hydroxymethyl derivative OTI-10.

Reagents and conditions: (a) $\mathrm{LiAlH}_{4}\left(2.00 \mathrm{~mol}\right.$ eq), THF (abs), from $0{ }^{\circ} \mathrm{C}$ to rt, $16 \mathrm{~h}$; (b) $\mathrm{HBr}(48 \%)(1.12 \mathrm{~mol}$ eq), toluene, $70{ }^{\circ} \mathrm{C}, 20 \mathrm{~min}$; (c) 3,4-dihydropyran (DHP) (1.16 mol eq), PPTS (pyridinium $p$-toulenesulfonate) (0.10 mol eq), DCM (abs), reflux, $30 \mathrm{~min}$; (d) (1) $\mathrm{CaH}_{2}$ (1.19 mol eq), DMF (abs), $80{ }^{\circ} \mathrm{C}, 30 \mathrm{~min}$, (2) 11 (1.47 mol eq), from rt to $80{ }^{\circ} \mathrm{C}, 1 \mathrm{~h}$; (e) $\mathrm{HCl}$ (conc) $/ \mathrm{H}_{2} \mathrm{O}(1 / 10)$, dioxane, $90{ }^{\circ} \mathrm{C}, 8 \mathrm{~h}$.

\section{Determination of enzyme inhibitory activities}

Inhibitors OTI-(7-10) were tested for their ability to inhibit the reduction of $D, L$ glyceraldehyde using ALR2 isolated from the rat eye lenses. Unsubstituted benzyl analogue OTI-6 was used as a reference inhibitor. To assess selectivity we used a structurally related detoxification enzyme (an antitarget), aldehyde reductase (ALR1) isolated from the rat kidneys. ${ }^{13}$ 
Table 1. Results of in vitro enzyme assays of the novel ALR2 inhibitors OTI-(7-10) in comparison with the unsubstituted parent compound OTI-6 and previously developed inhibitors Cemtirestat and Epalrestat.

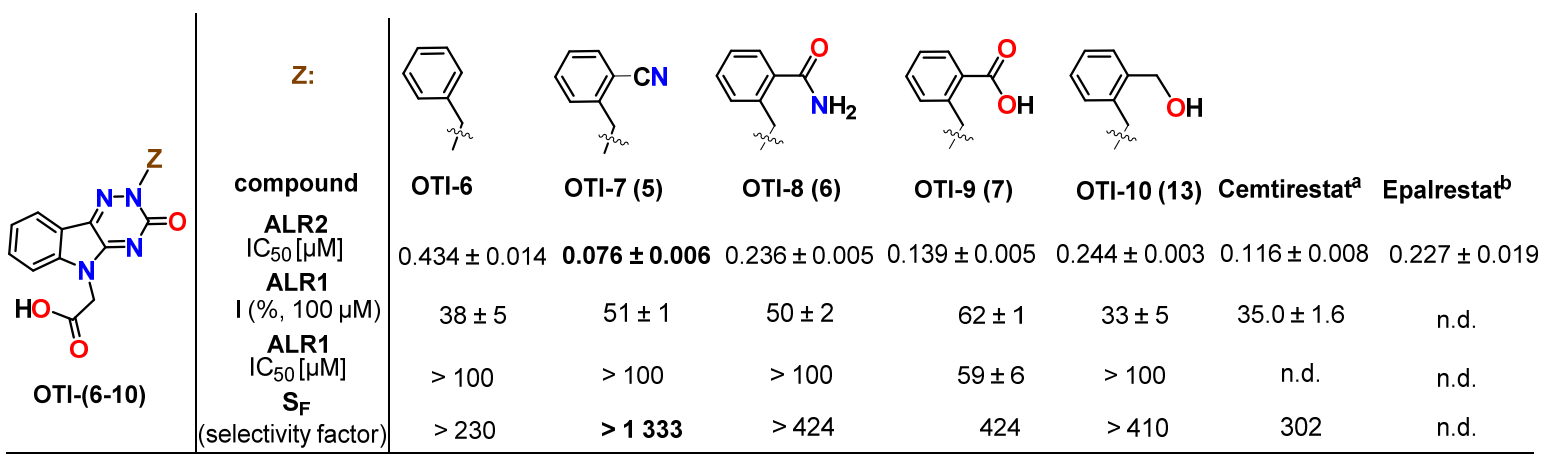

${ }^{\text {a}}$ Hlaváč et al. (2020), ${ }^{13}$ bMajekova et al. (2017) (measured in $1 \%$ DMSO), ${ }^{26}$ n.d.-not determined. Results are means \pm SD from minimum of three independent repetitions. $I$ is the $\%$ of enzyme inhibition observed at $100 \mu \mathrm{M}$ inhibitor concentration. Selectivity factor: $\mathrm{S}_{\mathrm{F}}=\mathrm{IC}_{50}(\mathrm{ALR} 1) / \mathrm{IC}_{50}(\mathrm{ALR} 2)$.

According to the results we found out that all substituted $N$-(benzyl) derivatives OTI-(7-10) exhibited from 2 to 6-fold better inhibitory efficacy than unsubstituted analogue OTI-6. In addition, they also revealed low inhibition of ALR1 antitarget, which resulted from a good to an excellent enzyme selectivity. (Table 1) Obtained results confirmed proposed additional interactions of substituted $N$-(benzyl) derivatives OTI-(7-10) within the interactive pocket of ALR2. The best ALR2 inhibition $\left(\mathrm{IC}_{50}=76 \mathrm{nM}\right)$ and selectivity relative to ALR1 $\left(\mathrm{S}_{\mathrm{F}}>1333\right)$ was obtained for OTI-7 derivative containing a $N$-(2-cyanobenzyl) group. Predicted binding position of OTI-7 in an active site of ALR2 shows a H-bond of a cyano group with Ala299 from backbone $(2.4 \AA)$. Moreover, the aromatic ring of a benzyl moiety forms two $\pi-\pi$ interactions with Trp219 (3.9 and 4.6 A). (Fig. 3)

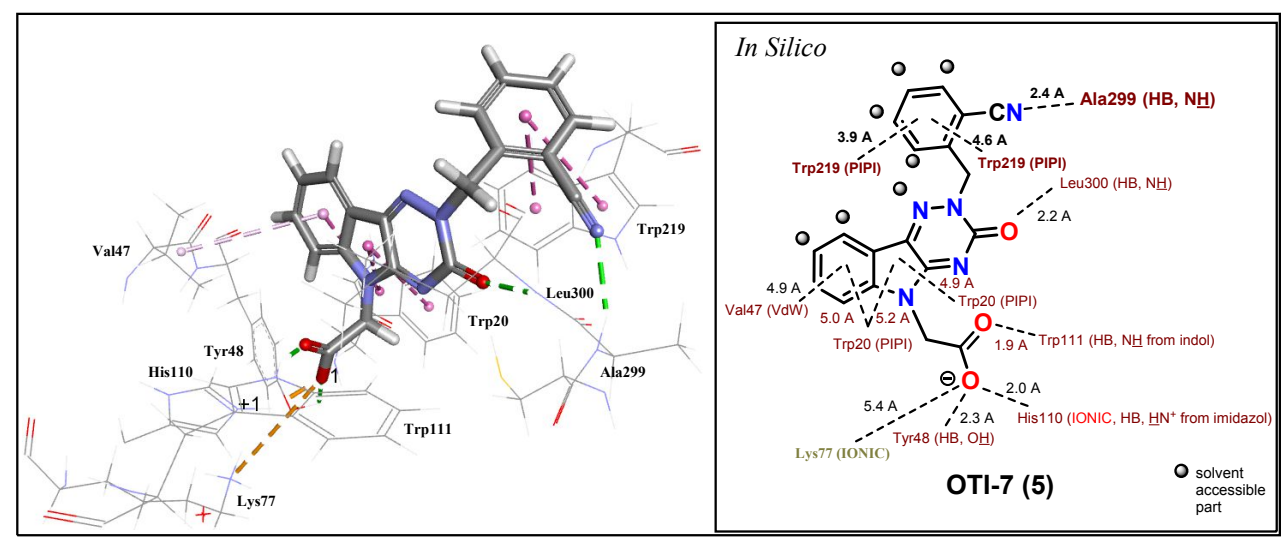

Figure 3. Predicted pose and interactions of OTI-7 (5) in a binding site of an ALR2 (PDB: 4QX4). 
In spite of predicted similar positions and interactions of the derivatives OTI-10 and OTI-7, OTI-10 exhibited about 3-times lower inhibitory activity characterized with $\mathrm{IC}_{50}=241 \mathrm{nM}$.

The additional reason of lower activity of OTI-10 could be desolvation and rotation penalty caused by a $-\mathrm{CH}_{2} \mathrm{OH}$ group. Desolvation penalty effect has been a subject of our recent publication. ${ }^{14}$ Derivatives OTI-(8,9) $\left(-\mathrm{CONH}_{2},-\mathrm{COOH}\right.$, resp.) revealed 2 to 3 -fold lower inhibitory activity in comparison to OTI-7 (-CN). Besides desolvation penalty, the lower activity of a carbamoyl derivative OTI-8 could be also caused by conformational penalty of $\mathrm{CONH}_{2}$ group. Symmetry of delocalized carboxylate group in OTI-9 (-COO${ }^{-}$) exhibited better inhibition activity than OTI-8 $\left(-\mathrm{CONH}_{2}\right)$ and OTI-10 $\left(-\mathrm{CH}_{2} \mathrm{OH}\right)$. In addition, outer part of a studied pocket and a benzyl group are well water accessible (Fig. 4) and hence a benzyl group could provide two conformers. A first conformer allows formation of the predicted $\mathrm{H}$ bond with an orientation of a polar group inside the pocket and a second conformer prefers orientation toward the solvent. Consequently, very polar groups would not be oriented inside the pocket, where the predicted H-bonds could be formed, but owing to solvation they would remain oriented toward a water environment out of the pocket. Therefore significant H-bond with Ala299 or Leu301 would not be formed as was predicted and thus the least solvated derivative OTI-7 revealed the highest inhibitory activity.

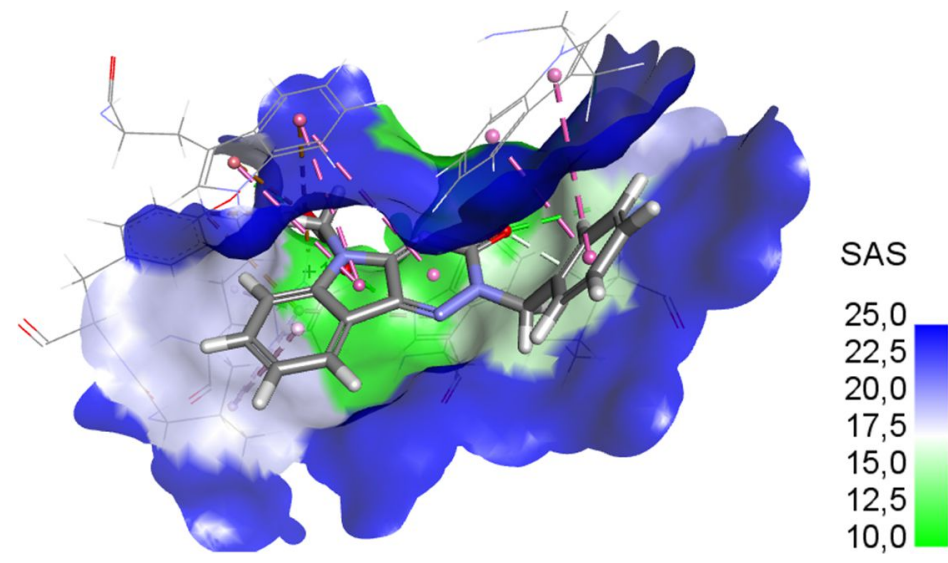

Figure 4. Solvents Accessible Surface of the unsubstituted benzyl derivative OTI-6. Blue colour indicates water accessible part.

In order to determine drug-like parameters, molecular obesity indices for compounds OTI-(610) were calculated (Table 2). The parameters take into account size, inhibitory efficacy and lipophilicity. 
Table 2. Physicochemical properties and molecular obesity indices calculated for compounds OTI-(6-10).

\begin{tabular}{|c|c|c|c|c|c|c|c|c|c|c|}
\hline Compound & $\begin{array}{c}\text { MW } \\
<500^{\mathrm{h}}\end{array}$ & $\mathbf{p K a}^{\mathrm{b}}$ & $\mathbf{p I C}_{\mathbf{5 0}}$ & $\mathbf{L o g}^{\mathrm{a}}$ & $\mathbf{L O g D}^{\mathrm{a}}$ & $\mathbf{L E}^{\mathrm{c}}$ & $\mathbf{B E I}^{\mathrm{d}}$ & $\mathbf{L L E}^{\mathrm{e}}$ & $\mathbf{L E L P}^{\mathrm{f}}$ & TPSA $^{\mathrm{g}}$ \\
$<5^{\mathrm{h}}$ & & & & & & & & & & \\
$>14.3^{\mathrm{h}}$ & $>3.8^{\mathrm{i}}$ & $<7.5^{\mathrm{h}}$ & $60-140^{\mathrm{h}}$ \\
\hline OTI6 & 334.33 & 4.14 & 6.36 & 2.04 & -0.98 & 0.36 & 19.05 & 4.32 & 5.72 & 90.01 \\
\hline OTI7 & 359.34 & 4.14 & 7.12 & 1.61 & -1.24 & 0.37 & 19.83 & 5.51 & 4.37 & 113.8 \\
\hline OTI8 & 377.35 & 4.14 & 6.63 & 1.05 & -1.25 & 0.33 & 17.58 & 5.57 & 3.18 & 133.1 \\
\hline OT19 & 378.34 & $4.14 / 4.15^{*}$ & 6.86 & 1.39 & -2.50 & 0.34 & 18.14 & 5.47 & 4.05 & 127.31 \\
\hline OTI10 & 364.35 & 4.14 & 6.61 & 1.31 & -1.53 & 0.34 & 18.17 & 5.30 & 3.82 & 110.24 \\
\hline
\end{tabular}

${ }^{\mathrm{a}}$ Calculated with MedChem Designer ${ }^{\mathrm{TM}}{ }^{\mathrm{b}}$ Calculated with Pallas 3.112, $\log D$ represents the logarithm of the distribution ratio in octanol-buffer [pH 7] ${ }^{\mathrm{c}} \mathrm{Ligand}$ efficiency, $\mathrm{LE}=-1.4 \log \left(\mathrm{IC}_{50}\right) / N, N$ : number of heavy atoms ${ }^{\mathrm{d} B i n d i n g}$ efficiency index, $\mathrm{BEI}=\mathrm{pIC}_{50} / \mathrm{MW}{ }^{\mathrm{e}}$ Lipophilic ligand efficiency, $\mathrm{LLE}=\mathrm{pIC}_{50}-\log \mathrm{P}{ }^{\mathrm{f}}$ Ligand efficiency-dependent lipophilicity, LELP $=\log P /$ LE. ${ }^{\mathrm{g}}$ Topological polar surface area, TPSA calculated with MedChem Designer ${ }^{\mathrm{TM}}{ }^{\mathrm{h}}$ Optimal drug values. ${ }^{15-17} \mathrm{i}$ Mean value for successful lead. ${ }^{17 *} \mathrm{BnCOOH}$.

Calculated values of the ligand efficacy (LE) and the binding efficiency index (BEI) for all inhibitors OTI-(6-10) were found in the range of optimal values ( $>0.3$ and $>14.7$, resp). In addition, all novel compounds exhibited favourable lipophilic ligand efficiency parameter (LLE) values above the limit 3.8, important for a successful lead. All compounds OTI-(6-10) showed ligand-efficiency-dependent lipophilicity (LELP) in recommended range $(<7.5)$, which implies good drug-likeness of all developed inhibitors. Moreover, all compounds have appropriate topological polar surface area (TPSA) $\left(60-140 \AA^{2}\right)$ predicting good oral absorbtion.

Based on the results from screening and the SAR conclusions, we have proposed other appropriate $N$-benzyl(oxotriazinoindole) analogues shown in Fig. 5. These derivatives should preserve similar interactions as the parent compounds within a studied ALR2 pocket and they should have lower desolvation and/or conformational penalties. Acetyl derivative OTI-8a (an analogue to amide derivative OTI-8) possesses lower polarity and solvation. Methyl ester OTI-9a is a less polar analogue to carboxylic acid OTI-9. Besides its lower solvation, it could also possess better penetration through the cell membrane in contrast to OTI-9. In addition, nitro derivative OTI-9b should be less solvated because of its lower polarity and with no conformational penalty considering its symmetric delocalized structure (Fig. 5) although $-\mathrm{NO}_{2}$ group is less favorable in drug development due its potential toxicity. More detailed predicted 
interaction diagrams of newly proposed analogues OTI-(8a-9a,b) are described in the Supporting information of this paper.

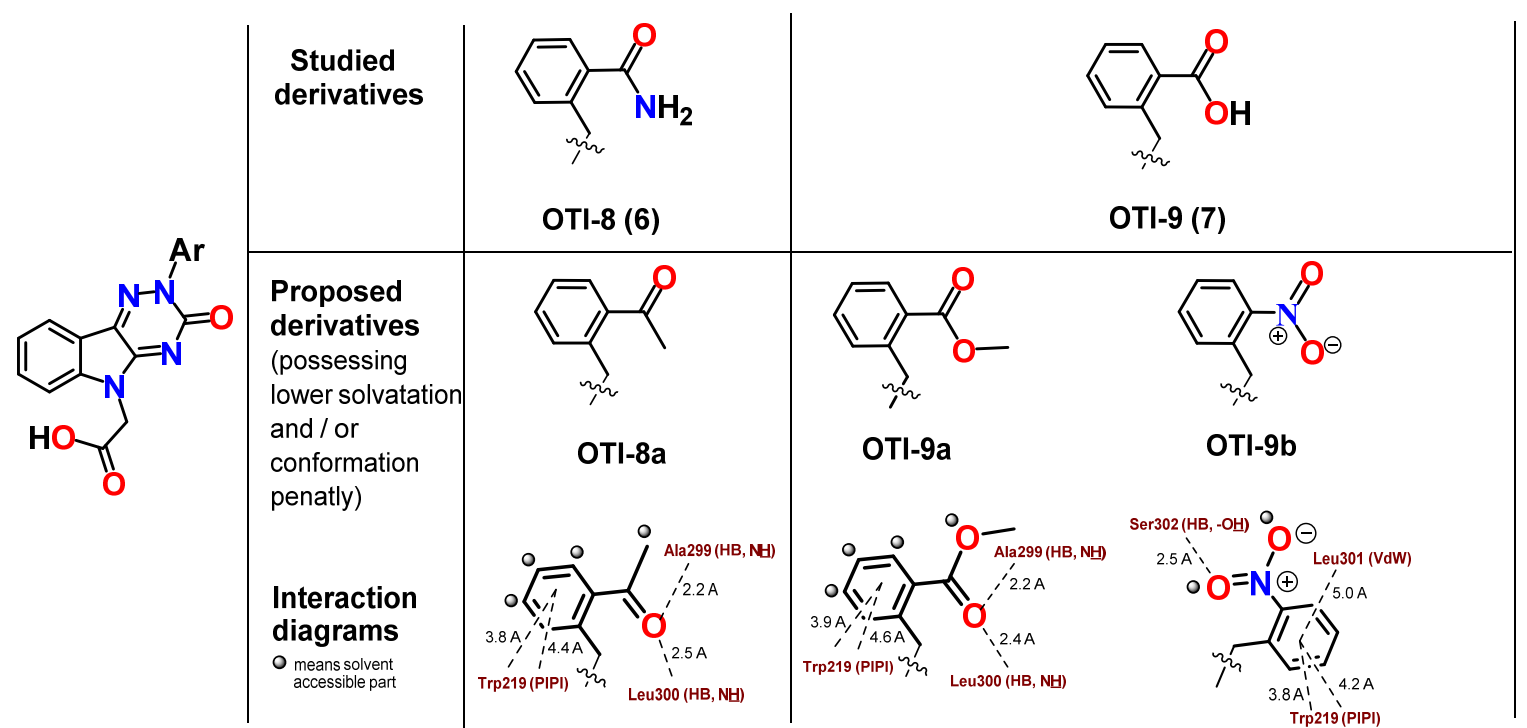

Figure 5. The structures of studied inhibitors OTI-(8,9) and their proposed promising analogues OTI-(8a-9a,b).

Apart from OTI-(8a-9a,b) analogues, we proceeded with a proposal of other $N$-substituted analogues possessing lipophilic naphthalene derivatives OTI-(11-13) with favourable predictions comprising four $\pi-\pi$ interactions with Trp219 and Van der Waals interactions with Ala299 or Leu301. (Fig. 6)

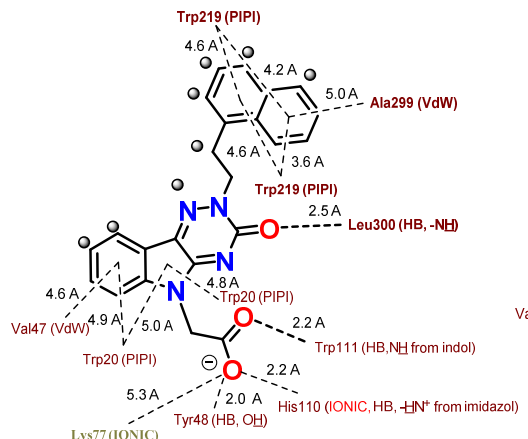

OTI-11

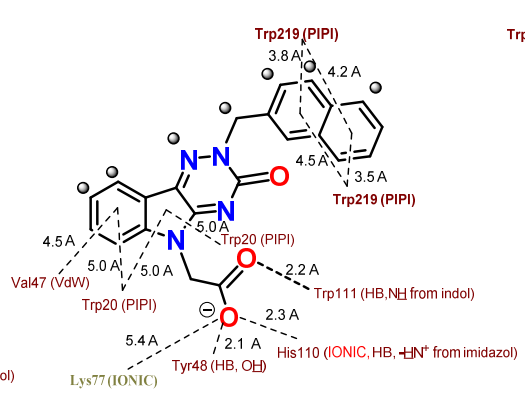

OTI-12

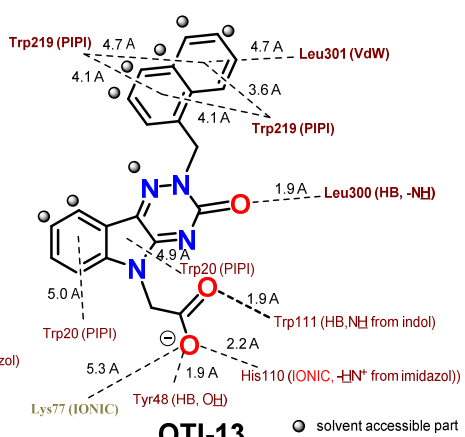

OTI-13

Figure 6. Proposed naphthalene derivatives OTI-(11-13), their predicted poses and interactions.

Other polycyclic derivatives with favourable predictions and lower solvation include OTI-14 and OTI-15 derivatives. They contain 3,4-dihydronaphtalen-2(1H)-one and 2,3-dihydro- $1 H$ inden-1-one moiety, resp. Besides their $\pi-\pi$ interactions with Trp219, they also revealed Hbond with Ala299 and OTI-15 also with Leu300. (Fig. 7) 

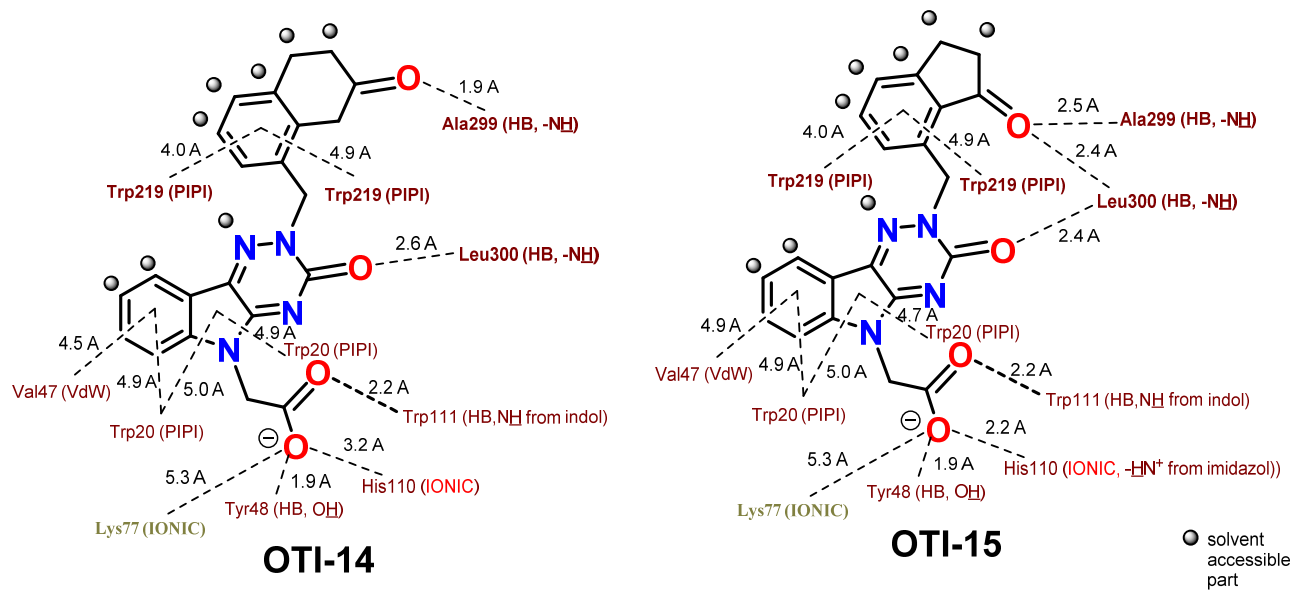

Figure 7. Predicted ALR2 poses and interactions of proposed polycyclic derivatives OTI-14 and OTI-15.

\section{Conclusions}

We have developed four novel $N$-benzyl(oxotriazinoindole) inhibitors OTI-(7-10), possessing polar functional groups (-CN, $-\mathrm{CONH}_{2},-\mathrm{COOH},-\mathrm{CH}_{2} \mathrm{OH}$, resp.) in ortho position on a benzyl group. They exhibited 2 to 6 -fold better inhibitory activity than their $N$-(benzyl) lead compound OTI-6. Our findings confirmed expected additional interactions of novel OTI derivatives in a studied binding pocket of ALR2. Moreover, the novel derivatives also exhibited ALR1 inhibitory activity in high micromolar concentrations, which resulted in good to excellent ALR1 / ALR2 selectivity for developed compounds OTI-(7-10). The most efficient ALR2 inhibitor OTI-7 $\left(\mathrm{IC}_{50}=76 \mathrm{nM}\right)$ contains a planar and less solvated -CN functional group on a benzyl ring. Other derivatives OTI-(8-10) $\left(-\mathrm{CONH}_{2},-\mathrm{COOH}\right.$ and $\mathrm{CH}_{2} \mathrm{OH}$, resp.) revealed 2 to 3 -fold lower ALR2 inhibitory activity than OTI-7. The reason of lower activity of derivatives OTI-(8-10) was assigned to a desolvation and possibly also to a conformational penalty. Considering these effects, we have proposed novel analogues OTI(8a-9a,b) which preserve the favorable interactions of their parent compounds within ALR2 while possessing less polar substituents. Therefore, improved inhibition efficacies and druglike properties of the novel derivatives are expected. Several polycyclic $N$-substituted derivatives OTI-(11-15) have also been selected due to their favorable proposed interactions in ALR2 pocket. 


\section{Experimental}

\section{Computer predictions}

The structure of hu-ALR2 protein in a complex with NADP+ (PDB: 4QX4) ${ }^{12}$ was used for our predictions. The optimized conformers of the proposed ligands were docked into the enzyme-cofactor complex by UCSF software Dock Blaster methodology. ${ }^{18}$ The predicted poses of ligands in an active site of ALR2 enzyme were analysed and used for composition of OTI-(7-10) intermolecular interactions diagrams. (Fig. 2-3 and 5-6) The protein conformer of a human recombinant enzyme AKR1B1 from the complex (PDB: 4QX4), possessing two 3E2 (cemtirestat) ligands and NAP $\left(\mathrm{NADP}^{+}\right)$cofactor, was used for modelling, grid generation and docking. The structures of ligands were proposed by molecular modelling in the Discovery Studio Visualizer software (release 2019) from Biovia. ${ }^{19}$ The optimal 3D structures of proposed ligands together with their protomers, tautomers and isomers were generated by a Ligand Preparation tool of the Maestro software (release 2016) from Schrodinger at software standard predifined conditions and $\mathrm{pH}=7.0 / \pm 1 .^{20}$ The target protein was prepared for docking in a Protein Preparation Wizard tool of the Maestro software by standard predefined conditions at $\mathrm{pH} 7.0$, while the present water molecules were removed. The target hydrogens were minimized, invalid bond order corrected, missing side chains added and detected amino acid alternative positions selected. Afterwards, a Receptor Glide Grid Generation tool of the Maestro software was used at standard predefined conditions exploiting binding position of 3E2 402 ligand, while the second 3E2 403 ligand was removed before grid generation. The optimal conformers of the ligands were docked into the enzyme-cofactor complex by a Glide Docking tool of the Maestro software at standard predefined conditions in an extra precision (XP) mode with flexible ligand sampling, rewarding intramolecular hydrogen bonds and enhancing planarity of conjugated pi groups. Only the best pose for each ligand was recorded. The most promising ligands were selected based on their score from docking experiments and the results of their intermolecular interaction analysis with target amino acid residues.

\section{Chemistry}

Melting points were measured by Barnstead Electrothermal IA9200 and are uncorrected. ${ }^{1} \mathrm{H}-$ and ${ }^{13} \mathrm{C}$-NMR spectra were recorded on Varian Gemini $(300 / 600 \mathrm{MHz}$ and $75 / 150 \mathrm{MHz}$, resp.), chemical shifts are given in parts per million (ppm), tetramethylsilane was used as an internal standard. DMSO- $d_{6}$ and $\mathrm{CDCl}_{3}$ were used as a solvent, unless otherwise specified. IR spectra were acquired on FT-IR-ATR REACT IR 1000 (ASI Applied Systems) with diamond 
probe and MTS detector. Mass spectra were performed on LC-MS (Agilent Technologies 1200 Series equipped with Mass spectrometer Agilent Technologies 6100 Quadrupole LCMS). The course of the reactions was followed by TLC analysis (Merck Silica gel 60 F254). UV lamp (254 nm) and iodine vapours were used for visualization of TLC spots. Starting chemicals were purchased from Sigma-Aldrich, Fluorochem, AlfaAesar or Acros vendors. All tested compounds OTI-(6-10) possess purity over $95 \%$. Their purity was determined by combustion analysis, HPLC and melting point. Combustion analysis was measured on vario MICRO cube (elemental analysis found values for carbon, hydrogen, and nitrogen within 0.4 $\%$ of the calculated values for their molecular formulas). Detailed descriptions of the intermediates and the final products OTI-(7-10), their predicted poses in ALR2 and spectra figures are deposited in the Supporting information of this paper.

\section{Ethyl 2-(3-oxo-2,3-dihydro-5H-[1,2,4]triazino[5,6-b]indol-5-yl)acetate}

To a solution of $100 \mathrm{mg}(0.41 \mathrm{mmol}, 1.00 \mathrm{~mol} \mathrm{eq})$ of 1 (OTI) dissolved in $30 \mathrm{ml}$ of EtOH (abs), $1.00 \mathrm{ml}$ of $\mathrm{H}_{2} \mathrm{SO}_{4}$ (conc) was added and the reaction stirred at reflux under Ar. After $6 \mathrm{~h}$ TLC analysis confirmed a presence of a new product without any starting compound. The mixture was cooled down and excess of EtOH evaporated by RVE. Crude product was dissolved in $30 \mathrm{ml}$ of DCM, washed with water $(5 \times 30 \mathrm{ml})$ and saturated aq solution of $\mathrm{NaHCO}_{3}(3 \times 30 \mathrm{ml})$. Separated organic layer was dried over $\mathrm{Na}_{2} \mathrm{SO}_{4}$, filtered and concentrated under reduced pressure yielding $85.0 \mathrm{mg}(0.31 \mathrm{mmol}, 76 \%)$ of ester 2 as an orange solid product. Novelty: ethyl 2-(3-oxo-2,3-dihydro-5H-[1,2,4]triazino[5,6- $b]$ indol-5yl)acetate (2) is described in the literature by its M.P., ${ }^{1} \mathrm{H}-\mathrm{NMR},{ }^{13} \mathrm{C}-\mathrm{NMR}$, IR, MS and elemental analysis. ${ }^{13}$ M.p.: 247.0 - $253.0{ }^{\circ} \mathrm{C}$ [DCM], lit.: $248.0-252.0{ }^{\circ} \mathrm{C}[\mathrm{MeOH} / \mathrm{DCM}] .{ }^{13}$

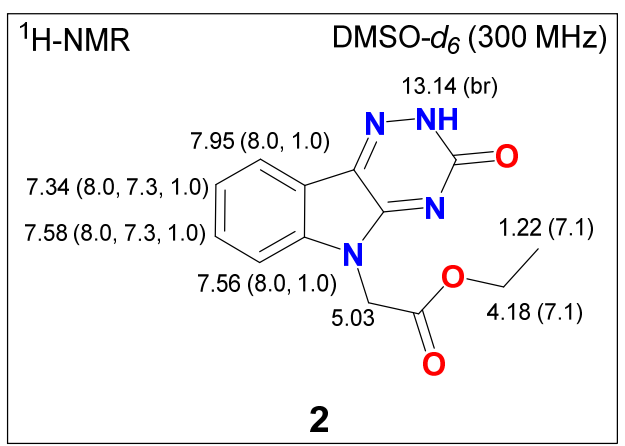

${ }^{1} \mathrm{H}$ NMR (300 MHz, DMSO-d6): $\delta 13.14$ (br s, 1H, -NH-), 7.95 (dd, $1 \mathrm{H}, J(8,9)=8.0 \mathrm{~Hz}$, $J(7,9)=1.0 \mathrm{~Hz}, \mathrm{H}-\mathrm{C}(9)), 7.58(\mathrm{ddd}, 1 \mathrm{H}, J(6,7)=8.0 \mathrm{~Hz}, J(7,8)=7.3 \mathrm{~Hz}, J(7,9)=1.0 \mathrm{~Hz}, \mathrm{H}-$ $\mathrm{C}(7)), 7.56(\mathrm{dd}, 1 \mathrm{H}, J(6,7)=8.0 \mathrm{~Hz}, J(6,8)=1.0 \mathrm{~Hz}, \mathrm{H}-\mathrm{C}(6)), 7.34(\mathrm{ddd}, 1 \mathrm{H}, J(8,9)=8.0 \mathrm{~Hz}$, 
$J(7,8)=7.3 \mathrm{~Hz}, J(6,8)=1.0 \mathrm{~Hz}, \mathrm{H}-\mathrm{C}(8)), 5.03\left(\mathrm{~s}, 2 \mathrm{H}, \mathrm{NCH}_{2} \mathrm{COOEt}\right), 4.18(\mathrm{q}, 2 \mathrm{H}$, $\left.J(\mathrm{CH} 2, \mathrm{CH} 3)=7.1 \mathrm{~Hz},-\mathrm{OCH}_{2} \mathrm{CH}_{3}\right), 1.22\left(\mathrm{t}, 3 \mathrm{H}, \mathrm{J}\left(\mathrm{CH}_{2}, \mathrm{CH}_{3}\right)=7.1 \mathrm{~Hz},-\mathrm{OCH}_{2} \mathrm{CH}_{3}\right)$.

\section{Ethyl 2-[2-(2-cyanobenzyl)-3-oxo-2,3-dihydro-5H-[1,2,4]triazino[5,6-b]indol-5- yl]acetate (4)}

To a solution of $100.0 \mathrm{mg}(0.37 \mathrm{mmol}, 1.00 \mathrm{~mol} \mathrm{eq}) 2$ in $3 \mathrm{ml}$ DMF (abs), $18.5 \mathrm{mg}(0.44$ mmol, $1.19 \mathrm{~mol} \mathrm{eq}$ ) of $\mathrm{CaH}_{2}$ was added and the reaction stirred at $80{ }^{\circ} \mathrm{C}$ for $30 \mathrm{~min}$. Then, the mixture was cooled to $\mathrm{rt}$ and $86.5 \mathrm{mg}(0.44 \mathrm{mmol}, 1.19 \mathrm{~mol} \mathrm{eq})$ of benzonitrile 3 was added portionwise and the mixture stirred at $80{ }^{\circ} \mathrm{C}$ within $1 \mathrm{~h}$. After consumption of 2 (confirmed by a TLC analysis) the reaction was cooled down in an ice bath, $10 \mathrm{ml}$ of water added and the reaction stirred for $10 \mathrm{~min}$. Resulting mixture was extracted with DCM (3 x $15 \mathrm{ml}$ ), a combined organic phase washed with brine $(3 \times 20 \mathrm{ml})$, dried over $\mathrm{Na}_{2} \mathrm{SO}_{4}$, filtered and concentrated under reduced pressure. A crude product was purified by FLC $\left(\mathrm{SiO}_{2}, \mathrm{Hex} / \mathrm{EA}=\right.$ $1 / 5)$ to give $128 \mathrm{mg}(0.33 \mathrm{mmol}, 90 \%)$ of $\mathbf{4}$ as an orange solid material. Novelty: ethyl 2-[2(2-cyanobenzyl)-3-oxo-2,3-dihydro-5H-[1,2,4]triazino[5,6- $b]$ indol-5-yl]acetate (4) has not been described in the literature. M.p.: $175.0-180.0^{\circ} \mathrm{C}[\mathrm{Hex} / \mathrm{EA}]$.

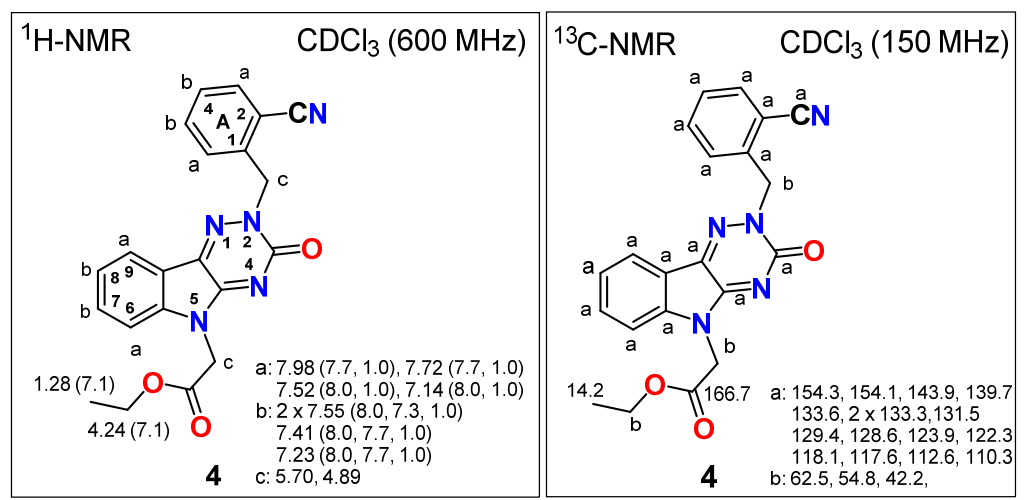

${ }^{1} \mathrm{H}-\mathrm{NMR}\left(600 \mathrm{MHz}, \mathrm{CDCl}_{3}\right): \delta 7.98,7.72,7.52$ and $7.14(4 \mathrm{x} \mathrm{dd}, 4 \mathrm{x} 1 \mathrm{H}, J(6,7$ or 8,9 or $\mathrm{A}_{3}, \mathrm{~A}_{4}$ or $\left.\mathrm{A}_{5}, \mathrm{~A}_{6}\right)=7.7$ or $8.0 \mathrm{~Hz}, J\left(6,8\right.$ or 7,9 or $\mathrm{A}_{3}, \mathrm{~A}_{5}$ or $\left.\mathrm{A}_{4}, \mathrm{~A}_{6}\right)=1.0 \mathrm{~Hz}, \mathrm{H}-\mathrm{C}\left(6,9, \mathrm{~A}_{3}\right.$ and A6)), $2 \times 7.55,7.41$ and $7.23\left(4 \mathrm{xddd}, 4 \times 1 \mathrm{H}, J\left(7,8\right.\right.$ or $\left.\mathrm{A}_{4}, \mathrm{~A}_{5}\right)=8.0 \mathrm{~Hz}, J\left(6,7\right.$ or 8,9 or $\mathrm{A}_{3}, \mathrm{~A}_{4}$ or $\left.\mathrm{A}_{5}, \mathrm{~A}_{6}\right)=7.7$ or $7.3 \mathrm{~Hz}, J\left(6,8\right.$ or 7,9 or $\mathrm{A}_{3}, \mathrm{~A}_{5}$ or $\left.\mathrm{A}_{4}, \mathrm{~A}_{6}\right)=1.0 \mathrm{~Hz}, \mathrm{H}-\mathrm{C}\left(7,8, \mathrm{~A}_{4}\right.$ and $\left.\left.\mathrm{A} 5\right)\right)$, 5.70 and $4.89\left(2 \times\right.$ s, $2 \mathrm{H},-\underline{\mathrm{C}}_{2} \mathrm{COOEt}$ and $\left.-\underline{\mathrm{C}}_{2} \mathrm{Ar}\right), 4.24\left(\mathrm{q}, 2 \mathrm{H}, J\left(\mathrm{CH}_{2}, \mathrm{CH}_{3}\right)=7.1 \mathrm{~Hz}\right.$, $\left.\mathrm{OC}_{2} \mathrm{CH}_{3}\right), 1.28\left(\mathrm{t}, 3 \mathrm{H}, J\left(\mathrm{CH}_{2}, \mathrm{CH}_{3}\right)=7.1 \mathrm{~Hz},-\mathrm{OCH}_{2} \underline{\mathrm{C}}_{3}\right) .{ }^{13} \mathrm{C}-\mathrm{NMR}\left(150 \mathrm{MHz}, \mathrm{CDCl}_{3}\right)$ : 166.7 (-COOEt), 154.3, 154.1, 143.9, 139.7, 133.6, 2 x 133.3, 131.5, 129.4, 128.6, 123.9, 122.3, 118.1, 117.6, 112.6, 110.3, 62.5, 54.8, 42.2 and $14.2\left(-\mathrm{OCH}_{2} \mathrm{CH}_{3}\right)$. FT-IR (solid, $\left.\mathrm{cm}^{-1}\right)$ : 2983 (w), 2931 (w), 2228 (m, -CN), 1738 (s), 1662 (s), 1633 (s), 1600 (s), 1568 (s), 1498 (m), 1478 (s), 1408 (s), 1373 (m), 1314 (w), 1274 (m), 1200 (s), 1131 (w), 1104 (s), 1052 (s), 1015 
(m), $955(\mathrm{~m}), 936(\mathrm{~m}), 874(\mathrm{w}), 786(\mathrm{~m}), 755(\mathrm{~s}), 730(\mathrm{~m}), 697(\mathrm{~m}), 670(\mathrm{~m}), 557(\mathrm{~m}), 486$ (w), $465(\mathrm{w}), 430(\mathrm{~s})$. MS (ESI m/z): 387.0 (95 \%) [M-e']. Anal. calcd for $\mathrm{C}_{21} \mathrm{H}_{17} \mathrm{~N}_{5} \mathrm{O}_{3}$ (387.39): C, 65.11; H, 4.42; N, 18.08; Found: C, 64.36; H, 4.49; N, 18.45.

\section{2-(2-(2-Cyanobenzyl)-3-oxo-2,3-dihydro-5H-[1,2,4]triazino[5,6-b]indol-5-yl)acetic acid 5 (OTI-7)}

To a solution of $100 \mathrm{mg}(0.26 \mathrm{mmol}, 1.00 \mathrm{~mol}$ eq) ester 4 in $20 \mathrm{ml}$ of MeOH, $20.6 \mathrm{mg}(0.52$ mmol, $2.00 \mathrm{~mol} \mathrm{eq}$ ) of $\mathrm{NaOH}$ in $3 \mathrm{ml}$ water was added and the mixture refluxed for $30 \mathrm{~min}$. After consumption of starting material 4 (confirmed by TLC analysis) the reaction mixture was cooled down in an ice bath and acidified with $1 \mathrm{M} \mathrm{HCl}$ to $\mathrm{pH}=3$. After $10 \mathrm{~min}$ of stirring, formed precipitate was filtered off, washed with ice water and dried under reduce pressure to yield $70.0 \mathrm{mg}(0.19 \mathrm{mmol}, 75 \%)$ of acid 5 (OTI-7) as a brown solid product. Novelty: 2-[2-(2-cyanobenzyl)-3-oxo-2,3-dihydro-5H-[1,2,4]triazino[5,6- $b]$ indol-5-yl]acetic acid 5 (OTI-7) has not been described in the literature. M.p.: $280.9-284.5{ }^{\circ} \mathrm{C}[\mathrm{MeOH} /$ $\left.\mathrm{H}_{3} \mathrm{O}^{+}\right]$.

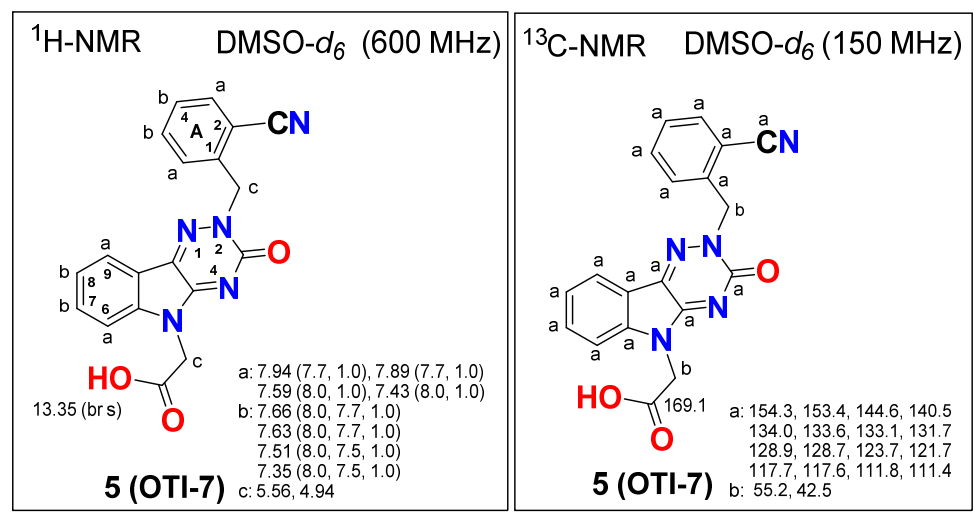

${ }^{1} \mathrm{H}-\mathrm{NMR}\left(600 \mathrm{MHz}, \mathrm{DMSO}-d_{6}\right): \delta 13.35$ (br s, $\left.1 \mathrm{H},-\mathrm{COOH}\right), 7.94,7.89,7.59$ and 7.43 (4 x dd, $4 \times 1 \mathrm{H}, J\left(6,7\right.$ or 8,9 or $\mathrm{A}_{3}, \mathrm{~A}_{4}$ or $\left.\mathrm{A}_{5}, \mathrm{~A}_{6}\right)=8.0$ or $7.7 \mathrm{~Hz}, J\left(6,8\right.$ or 7,9 or $\mathrm{A}_{3}, \mathrm{~A}_{5}$ or $\left.\mathrm{A}_{4}, \mathrm{~A}_{6}\right)=$ $\left.1.0 \mathrm{~Hz}, \mathrm{H}-\mathrm{C}\left(6,9, \mathrm{~A}_{3}, \mathrm{~A}_{6}\right)\right), 7.66,7.63,7.51$ and $7.35\left(4 \mathrm{x} \mathrm{ddd}, 4 \mathrm{x} 1 \mathrm{H}, J\left(7,8\right.\right.$ or $\left.\mathrm{A}_{4}, \mathrm{~A}_{5}\right)=8.0$ $\mathrm{Hz}, J\left(6,7\right.$ or 8,9 or $\mathrm{A}_{3}, \mathrm{~A}_{4}$ or $\left.\mathrm{A}_{5}, \mathrm{~A}_{6}\right)=7.7$ or $7.5 \mathrm{~Hz}, J\left(6,8\right.$ or 7,9 or $\mathrm{A}_{3}, \mathrm{~A}_{5}$ or $\left.\mathrm{A}_{4}, \mathrm{~A}_{6}\right)=1.0 \mathrm{~Hz}$, $\left.\mathrm{H}-\mathrm{C}\left(7,8, \mathrm{~A}_{4}, \mathrm{~A} 5\right)\right), 5.56$ and $4.94\left(2 \times \mathrm{s}, 2 \times 2 \mathrm{H},-\underline{\mathrm{C}}_{2} \mathrm{COOH}\right.$ and $\left.-\underline{\mathrm{C}}_{2} \mathrm{Ar}\right) .{ }^{13} \mathrm{C}-\mathrm{NMR}(150$ MHz, DMSO-d6): 169.1 (-COOH), 154.3, 153.4, 144.6, 140.5, 134.0, 133.6, 133.1, 131.7, 128.9, 128.7, 123.7, 121.7, 117.7, 117.6, 111.8, 111.4, 55.2, 42.5. FT-IR (solid, $\mathrm{cm}^{-1}$ ): 3300 2800 (br, COOH) 2226 (w), 1762 (m), 1626 (m), 1604 (s), 1572 (s), 1502 (m), 1468 (m), 1420 (m), 1381 (m), 1341 (m), 1316 (w), 1278 (m), 1229 (m), 1207 (m), 1162 (w), 1134 (w), $1115(\mathrm{w}), 1084(\mathrm{w}), 1058(\mathrm{w}), 1039(\mathrm{w}), 994(\mathrm{w}), 934(\mathrm{w}), 885(\mathrm{w}), 788(\mathrm{~s}), 767(\mathrm{~s}), 668(\mathrm{~m})$, $611(\mathrm{~m}), 584(\mathrm{~m}), 556(\mathrm{~m}), 499$ (w), 457 (w), 433 (s). MS (ESI m/z): $358.1(80 \%)$ [M-H $\left.{ }^{+}\right]$, 
$314.0(100 \%)\left[\mathrm{M}-\mathrm{CO}_{2}-\mathrm{H}^{+}\right]$. Anal. calcd for $\mathrm{C}_{19} \mathrm{H}_{13} \mathrm{~N}_{5} \mathrm{O}_{3}$ (359.35): C, 63.51; H, 3.65; N, 19.49

Found: C, 63.30; H, 3.60; N, 19.50 .

\section{2-[2-(2-Carbamoylbenzyl)-3-oxo-2,3-dihydro-5H-[1,2,4]triazino[5,6-b]indol-5- yl]acetic acid 6 (OTI-8)}

A solution of $20.0 \mathrm{mg}(0.05 \mathrm{mmol}, 1.00 \mathrm{~mol} \mathrm{eq})$ ester 4 in $1 \mathrm{ml}$ of $\mathrm{CF}_{3} \mathrm{COOH}$ (TFA) and 0.25 $\mathrm{ml}$ of $\mathrm{H}_{2} \mathrm{SO}_{4}$ (conc) was stirred at $70{ }^{\circ} \mathrm{C}$ for $6 \mathrm{~h}$. After complete consumption of the starting compound 4 (confirmed by a TLC analysis), the reaction was cooled down and $20 \mathrm{ml}$ of $\mathrm{H}_{2} \mathrm{O}$ and $20 \mathrm{ml}$ of brine added, and the mixture extracted with EA $(5 \times 15 \mathrm{ml})$. Combined organic layer was dried over $\mathrm{Na}_{2} \mathrm{SO}_{4}$, filtered and concentrated under reduced pressure. A crude product 6 (OTI-8) was purified by trituration with a mixture of Hex / EA to give $15.0 \mathrm{mg}$ (0.04 mmol, $77 \%)$ of acid 6 (OTI-8) as a solid compound. Novelty: 2-[2-(2carbamoylbenzyl)-3-oxo-2,3-dihydro-5H-[1,2,4]triazino[5,6- $b$ ]indol-5-yl]acetic acid 6 (OTI8) has not been described in the literature. M.p.: $221.3-225.1^{\circ} \mathrm{C}[\mathrm{EA}]$.

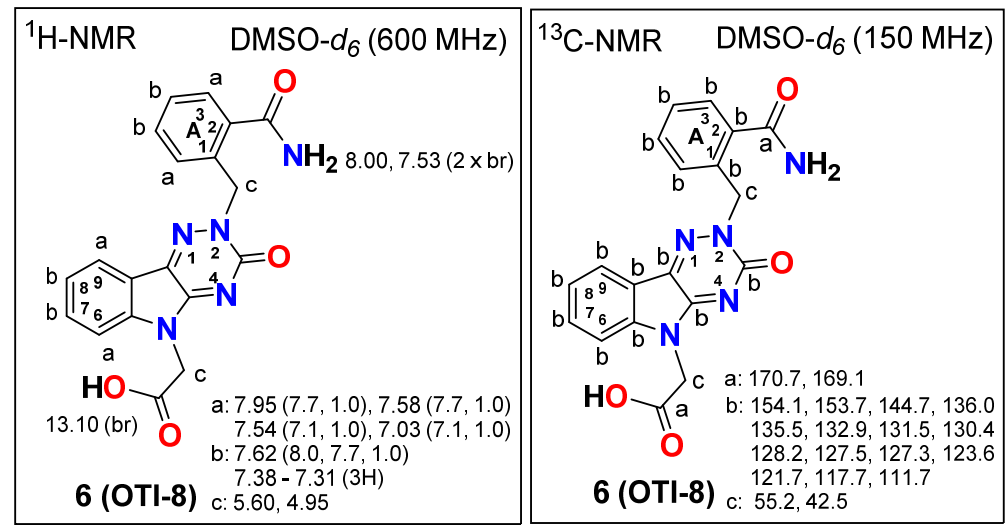

${ }^{1} \mathrm{H}-\mathrm{NMR}\left(600 \mathrm{MHz}, \mathrm{DMSO}-d_{6}\right): \delta 13.10$ (br s, $\left.1 \mathrm{H},-\mathrm{COOH}\right), 8.00$ and $7.53(2 \mathrm{x}$ br s, $2 \mathrm{x} 1 \mathrm{H},-$ $\left.\mathrm{ArCON}_{2}\right)$, 7.95, 7.58, 7.54 and $7.03\left(4 \mathrm{x} \mathrm{dd}, 4 \mathrm{x} 1 \mathrm{H}, J\left(6,7\right.\right.$ or 8,9 and $\mathrm{A}_{3}, \mathrm{~A}_{4}$ or $\left.\mathrm{A}_{5}, \mathrm{~A}_{6}\right)=7.7$ or $7.1 \mathrm{~Hz}, J\left(6,8\right.$ or 7,9 or $\mathrm{A}_{3}, \mathrm{~A}_{5}$ or $\left.\mathrm{A}_{4}, \mathrm{~A}_{6}\right)=1.0 \mathrm{~Hz}, \mathrm{H}-\mathrm{C}\left(6,9, \mathrm{~A}_{3}\right.$ and $\left.\left.\mathrm{A}_{6}\right)\right), 7.62$ and $7.38-$ $7.31\left(1 \mathrm{x}\right.$ ddd and $\mathrm{m}, 1 \mathrm{H}$ and $3 \mathrm{H}, J\left(7,8\right.$ or $\left.\mathrm{A}_{4}, \mathrm{~A}_{5}\right)=8.0 \mathrm{~Hz}, J\left(6,7\right.$ or 8,9 or $\mathrm{A}_{3}, \mathrm{~A}_{4}$ or $\left.\mathrm{A}_{5}, \mathrm{~A}_{6}\right)=$ $7.7 \mathrm{~Hz}, J\left(6,8\right.$ or 7,9 or $\mathrm{A}_{3}, \mathrm{~A}_{5}$ or $\left.\mathrm{A}_{4}, \mathrm{~A}_{6}\right)=1.0 \mathrm{~Hz}, \mathrm{H}-\mathrm{C}\left(7,8, \mathrm{~A}_{4}\right.$ and $\left.\left.\mathrm{A}_{5}\right)\right), 5.60$ and $4.95(2 \mathrm{x} \mathrm{s}$, $2 \times 2 \mathrm{H},-\underline{\mathrm{CH}}_{2} \mathrm{COOH}$ and $\left.-\underline{\mathrm{C}}_{2} \mathrm{Ar}\right) .{ }^{13} \mathrm{C}-\mathrm{NMR}\left(150 \mathrm{MHz}, \mathrm{DMSO}-d_{6}\right): 170.7,169.1,154.1$, $153.7,144.7,136.0,135.5,132.9,131.5,130.4,128.2,127.5,127.3,123.6,121.7,117.7$, 111.7, 55.2 and 42.5. FT-IR (solid, $\mathrm{cm}^{-1}$ ): 3357 (m), 3191 (m), 2959 (m), 2928 (m), $2858(\mathrm{w})$, 2342 (w), 1736 (s), 1671 (s), 1606 (s), 1578 (s), 1498 (m), 1465 (m), 1413 (m), 1375 (w), $1282(\mathrm{~m}), 1199$ (s), 1122 (s), 941 (m), 748 (s), 678 (m), 631 (m), 504 (w), 438 (m). MS (ESI $\mathrm{m} / \mathrm{z}): 378.0(100 \%)\left[\mathrm{M}+\mathrm{H}^{+}\right], 400.1(20 \%)\left[\mathrm{M}+\mathrm{Na}^{+}\right], 777.2(80 \%)\left[(2 \times \mathrm{M})+\mathrm{Na}^{+}\right]$. Anal. 
calcd for $\mathrm{C}_{19} \mathrm{H}_{15} \mathrm{~N}_{5} \mathrm{O}_{4}$ (377.36): C, 60.48; H, 4.01; N, 18.56; Found: C, 60.85; H, 4.39; N, 18.75

\section{2-\{[5-(Carboxymethyl)-3-oxo-3,5-dihydro-2H-[1,2,4]triazino[5,6-b]indol-2- yl]methyl\}benzoic acid 7 (OTI-9)}

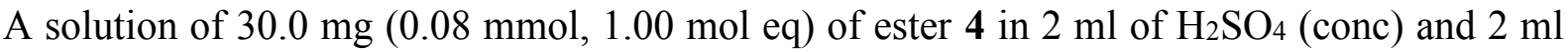
of $\mathrm{H}_{2} \mathrm{O}$ was stirred at $100{ }^{\circ} \mathrm{C}$ within $8 \mathrm{~d}$. After complete consumption of starting compound 4 and its amidic intermediate (confirmed by a TLC analysis), the reaction was cooled down, 20 $\mathrm{ml}$ of $\mathrm{H}_{2} \mathrm{O}$ added and the resulting mixture extracted with EA $(5 \times 15 \mathrm{ml})$. Combined organic layer was dried over $\mathrm{Na}_{2} \mathrm{SO}_{4}$, filtered and concentrated to a half of its volume. Then, the solution was placed into a refrigerator, where the product 7 (OTI-9) precipitated. After filtration, crude product was triturated with a mixture of Hex / EA to give $12.0 \mathrm{mg}(0.03$ mmol, $41 \%$ ) of bisacid 7 (OTI-9) as a yellow solid compound. Novelty: 2-\{[5(carboxymethyl)-3-oxo-3,5-dihydro- $2 H$-[1,2,4]triazino[5,6- $b]$ indol-2 yl]methyl $\}$ benzoic acid 7 (OTI-9) has not been described in the literature. M.p.: $260-277{ }^{\circ} \mathrm{C}$ (dec) [EA].

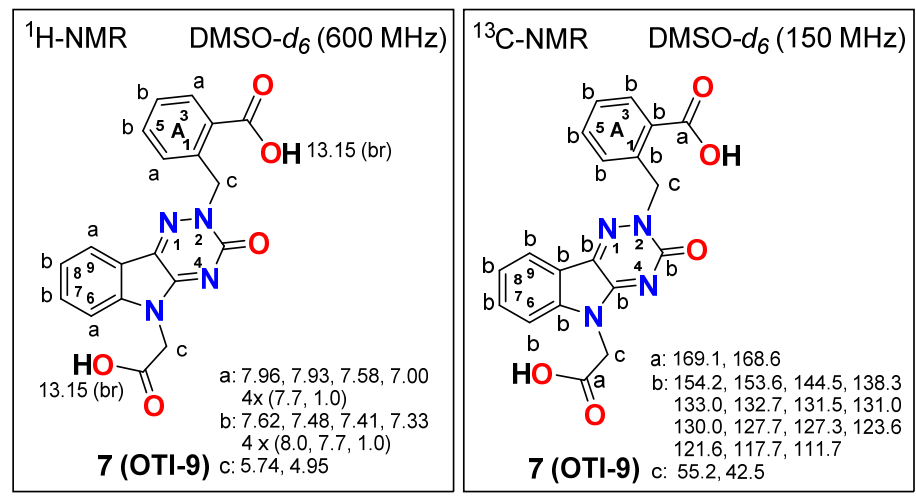

${ }^{1} \mathrm{H}-\mathrm{NMR}\left(600 \mathrm{MHz}, \mathrm{DMSO}-d_{6}\right): \delta 13.15(2 \mathrm{x}$ br s, $2 \times 1 \mathrm{H}, 2 \mathrm{x}-\mathrm{COOH}), 7.96,7.93,7.58$ and $7.00\left(4 \times \mathrm{dd}, 4 \times 1 \mathrm{H}, J\left(6,7\right.\right.$ or 8,9 or $\mathrm{A}_{3}, \mathrm{~A}_{4}$ or $\left.\mathrm{A}_{5}, \mathrm{~A}_{6}\right)=7.7 \mathrm{~Hz}, J\left(6,8\right.$ or 7,9 or $\mathrm{A}_{3}, \mathrm{~A}_{5}$ or $\left.\mathrm{A}_{4}, \mathrm{~A}_{6}\right)$ $=1.0 \mathrm{~Hz}, \mathrm{H}-\mathrm{C}\left(6,9, \mathrm{~A}_{3}\right.$ and $\left.\left.\mathrm{A}_{6}\right)\right), 7.62,7.48,7.41$ and $7.33\left(4 \mathrm{x}\right.$ ddd, $4 \mathrm{x} 1 \mathrm{H}, J\left(7,8\right.$ or $\left.\mathrm{A}_{4}, \mathrm{~A}_{5}\right)=$ $8.0 \mathrm{~Hz}, J\left(6,7\right.$ or 8,9 or $\mathrm{A}_{3}, \mathrm{~A}_{4}$ or $\left.\mathrm{A}_{5}, \mathrm{~A}_{6}\right)=7.7 \mathrm{~Hz}, J\left(6,8\right.$ or 7,9 or $\mathrm{A}_{3}, \mathrm{~A}_{5}$ or $\left.\mathrm{A}_{4}, \mathrm{~A}_{6}\right)=1.0 \mathrm{~Hz}, \mathrm{H}-$ $\mathrm{C}\left(7,8, \mathrm{~A}_{4}\right.$ and $\left.\left.\mathrm{A} 5\right)\right), 5.74$ and $4.95\left(2 \times \mathrm{s}, 2 \times 2 \mathrm{H},-\underline{\mathrm{C}}_{2} \mathrm{COOH}\right.$ and $\left.-\underline{\mathrm{CH}}_{2} \mathrm{Ar}\right) .{ }^{13} \mathrm{C}-\mathrm{NMR}(150$ MHz, DMSO-d6): 169.1, 168.6, 154.2, 153.6, 144.5, 138.3, 133.0, 132.7, 131.5, 131.0, 130.0, 127.7, 127.3, 123.6, 121.6, 117.7, 111.7, 55.2 and 42.5. FT-IR (solid, $\mathrm{cm}^{-1}$ ): 3000 - 2200 (br, COOH) 2822 (m), 2606 (m), 2088 (w), 1725 (m), 1688 (m), 1635 (m), 1602 (s), 1569 (s), 1499 (m), 1467 (m), 1406 (m), 1313 (m), 1225 (s), 1203 (s), 1134 (w), 1107 (m), 1056 (w), 968 (m), 940 (s), $827(\mathrm{w}), 788$ (s), 733 (s), 663 (s), $614(\mathrm{w}), 582(\mathrm{w}), 554(\mathrm{w}), 483(\mathrm{w}), 436$

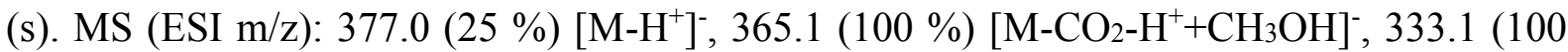


\%) $\left[\mathrm{M}-\mathrm{CO}_{2}-\mathrm{H}^{+}\right], 755(30 \%)\left[(2 \mathrm{x} \mathrm{M})-\mathrm{H}^{+}\right]$. Anal. calcd for $\mathrm{C}_{19} \mathrm{H}_{14} \mathrm{~N}_{4} \mathrm{O}_{5}(378.34): \mathrm{C}, 60.32 ; \mathrm{H}$, 3.73 ; N, 14.81; Found: C, 60.55; H, 4.05; N, 14.97 .

\section{1,2-Phenylenedimethanol (9)}

A solution of phthalic anhydride $8(440 \mathrm{mg}, 2.97 \mathrm{mmol}, 1.00 \mathrm{~mol} \mathrm{eq})$ in $15 \mathrm{ml}$ of THF (abs) was added dropwise at $0{ }^{\circ} \mathrm{C}$ to the stirred suspension of $\mathrm{LiAlH}_{4}(226 \mathrm{mg}, 5.96 \mathrm{mmol}, 2.00$ mol eq) in $20 \mathrm{ml}$ of THF (abs) within $30 \mathrm{~min}$. Then, the mixture was stirred overnight at room temperature. Afterwards, the reaction was cooled to $0{ }^{\circ} \mathrm{C}$ and $10 \mathrm{ml}$ of isopropanol added slowly, followed by methanol $(10 \mathrm{ml})$ and water $(10 \mathrm{ml})$. Obtained wax-like precipitate was filtered through Celite and obtained filtrate washed with EA and DCM. Organic solution was evaporated and aqueous mixture extracted with EA (3x $20 \mathrm{ml})$ and DCM (3x $10 \mathrm{ml})$. Combined organic layer was dried over $\mathrm{Na}_{2} \mathrm{SO}_{4}$, filtered and concentrated over reduced pressure totally yielding $385 \mathrm{mg}(2.79 \mathrm{mmol}, 94 \%)$ of diol 9 as a colourless oil, which solidified by storing in a refrigerator. Novelty: 1,2-phenylenedimethanol (9) is described in the literature by its M.P., ${ }^{1} \mathrm{H}-\mathrm{NMR},{ }^{13} \mathrm{C}-\mathrm{NMR}$, IR and HRMS. ${ }^{21}$ M.p.: $52.0-57.7{ }^{\circ} \mathrm{C}$ [EA / DCM], lit: $61-63{ }^{\circ} \mathrm{C}[\mathrm{EA}]^{21}$.

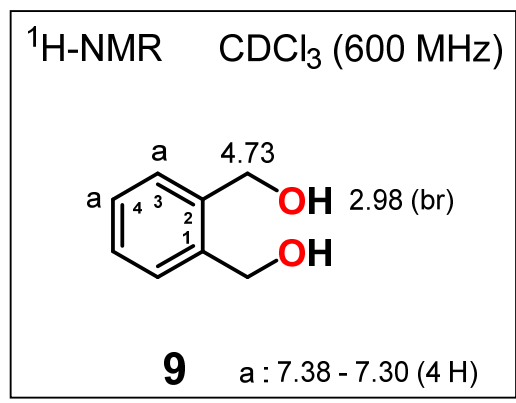

${ }^{1} \mathrm{H}-\mathrm{NMR}\left(600 \mathrm{MHz}, \mathrm{CDCl}_{3}\right): \delta 7.38-7.30(\mathrm{~m}, 4 \mathrm{H}, 2$ x H-C(3 and 4)), 4.73 (s, 4H, 2 x $\left.\mathrm{C}_{2} \mathrm{OH}\right), 2.98$ (br s, $2 \mathrm{H},-\mathrm{CH}_{2} \mathrm{O} \underline{\mathrm{H}}$ ).

\section{2-(Bromomethyl)phenyl]methanol (10)}

A solution of $105 \mathrm{mg}$ (0.76 mmol, $1.00 \mathrm{~mol} \mathrm{eq)} \mathrm{1,2-phenylenedimethanol} \mathrm{(9)} \mathrm{in} 20 \mathrm{ml}$ of toluene was heated to $70{ }^{\circ} \mathrm{C}$. At this temperature, $80 \mu \mathrm{l}(0.85 \mathrm{mmol}, 1.12 \mathrm{~mol}$ eq $)$ of $48 \%$ solution of $\mathrm{HBr}$ was added dropwise. After $20 \mathrm{~min}$, TLC analysis confirmed a presence of product $\mathbf{1 0}$ and a small amount of probably bis brominated side product. Reaction mixture was cooled down, neutralized with saturated aq solution of $\mathrm{Na}_{2} \mathrm{CO}_{3}$ and extracted with diethyl ether $(3 \times 15 \mathrm{ml})$. Combined organic layer was evaporated and resulted mixture purified by FLC $(\mathrm{Hex} / \mathrm{EA}=5 / 1)$ to afford $80.0 \mathrm{mg}(0.40 \mathrm{mmol}, 56 \%)$ of desired product 10 as a white solid compound. Novelty: 2-(bromomethyl)phenyl]methanol (10) is described in the literature 
by its M.P., ${ }^{1} \mathrm{H}-\mathrm{NMR}, \mathrm{IR}^{22}$ and MS spectra. ${ }^{23}$ M.p.: $61.0-63.8{ }^{\circ} \mathrm{C}\left[\mathrm{Et}_{2} \mathrm{O}\right]$, lit: $55{ }^{\circ} \mathrm{C}$ [hexane]. ${ }^{22}$

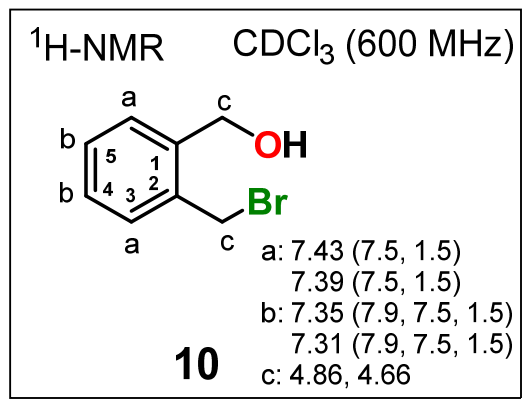

${ }^{1} \mathrm{H}-\mathrm{NMR}\left(600 \mathrm{MHz}, \mathrm{CDCl}_{3}\right): \delta 7.43$ and $7.39(2 \mathrm{x} \mathrm{dd}, 2 \times 1 \mathrm{H}, J(3,4$ or 5,6) $=7.5 \mathrm{~Hz}, J(3,5$ or $4,6)=1.5 \mathrm{~Hz}, \mathrm{H}-\mathrm{C}(3$ and 6$)), 7.35$ and $7.31(2 \times \mathrm{ddd}, 2 \times 1 \mathrm{H}, J(4,5)=7.9 \mathrm{~Hz}, J(3,4$ or 5,6) = $7.5 \mathrm{~Hz}, J(3,5$ or 4,6$)=1.5 \mathrm{~Hz}, \mathrm{H}-\mathrm{C}(4$ and 5$)), 4.86$ and $4.66\left(2 \times \mathrm{s}, 2 \times 2 \mathrm{H},-\underline{\mathrm{C}}_{2} \mathrm{OH}\right.$ and $\left.\mathrm{C}_{2} \mathrm{Br}\right)$.

\section{2-\{[2-(Bromomethyl)benzyl]oxy\}tetrahydro-2H-pyran (11)}

A solution of $245 \mathrm{mg}$ (1.22 mmol, $1.00 \mathrm{~mol} \mathrm{eq})$ of arylmethanol $10 \mathrm{in} 20 \mathrm{ml}$ of DCM (abs), $130 \mu \mathrm{l}$ (1.42 mmol, $1.16 \mathrm{~mol} \mathrm{eq})$ of 3,4-dihydro-2H-pyran (DHP) and $30.6 \mathrm{mg}$ (0.12 mmol, $0.10 \mathrm{~mol} \mathrm{eq}$ ) of PPTS (pyridinium $p$-toulenesulfonate), was stirred under Ar for $30 \mathrm{~min}$ at reflux. Subsequent TLC analysis confirmed presence of a new product and traces of two side products. Then, $20 \mathrm{ml}$ of $\mathrm{NaHCO}_{3}$ (sat aq sol) was added and resulting mixture extracted with DCM (3 x $15 \mathrm{ml})$. Combined organic layer was dried over $\mathrm{Na}_{2} \mathrm{SO}_{4}$, filtered and concentrated under reduced pressure yielding $310 \mathrm{mg}$ (1.09 mmol, $89 \%)$ of tetrahydropyran 11 as a colourless oily product. Novelty: 2-\{[2-(bromomethyl)benzyl]oxy $\}$ tetrahydro- $2 H$-pyran (11) is described in the literature by its ${ }^{1} \mathrm{H}-\mathrm{NMR}$ and crystal property description. ${ }^{24}$

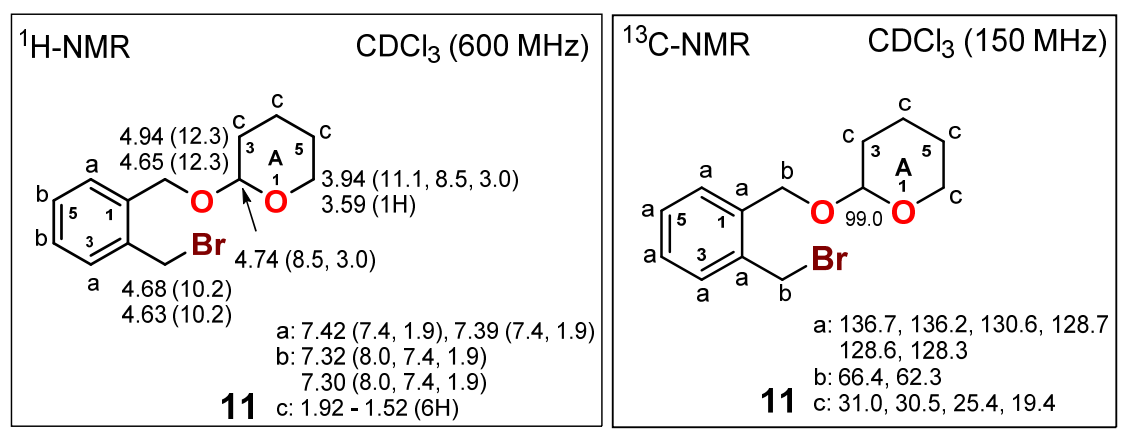

${ }^{1} \mathrm{H}-\mathrm{NMR}\left(600 \mathrm{MHz}, \mathrm{CDCl}_{3}\right): \delta 7.42$ and $7.39(2 \times \mathrm{dd}, 2 \times 1 \mathrm{H}, J(3,4$ or 5,6) $=7.4 \mathrm{~Hz}, J(3,5$ or $4,6)=1.9 \mathrm{~Hz}, \mathrm{H}-\mathrm{C}(3$ and 6)), 7.32 and $7.30(2 \mathrm{x} \mathrm{ddd}, 2 \times 1 \mathrm{H}, J(4,5)=8.0 \mathrm{~Hz}, J(3,4$ or 5,6) $=$ $7.4 \mathrm{~Hz}, J\left(3,5\right.$ or 4,6) = 1.9 Hz, H-C(4 and 5)), 4.94 (d, 1H, $\left.J_{\text {gem }}=12.3 \mathrm{~Hz},-\underline{\mathrm{C}}_{2} \mathrm{OTHP}\right), 4.74$ $\left(\mathrm{dd}, 1 \mathrm{H}, J\left(\mathrm{~A}_{2}, \mathrm{~A}_{3}\right)=8.5 \mathrm{~Hz}, J\left(\mathrm{~A}_{2}, \mathrm{~A}_{3}\right)=3.0 \mathrm{~Hz}, \mathrm{H}-\mathrm{C}_{\mathrm{A}}(2)\right), 4.68\left(\mathrm{~d}, 1 \mathrm{H}, J_{\text {gem }}=10.2 \mathrm{~Hz},-\right.$ 
$\left.\mathrm{CH}_{2} \mathrm{Br}\right), 4.65\left(\mathrm{~d}, 1 \mathrm{H}, J_{\mathrm{gem}}=12.3 \mathrm{~Hz},-\underline{\mathrm{H}}_{2} \mathrm{OTHP}\right), 4.63\left(\mathrm{~d}, 1 \mathrm{H}, J_{\mathrm{gem}}=10.2 \mathrm{~Hz},-\mathrm{CH}_{2} \mathrm{Br}\right), 3.94$ $\left(\mathrm{ddd}, 1 \mathrm{H}, J_{\mathrm{gem}}=11.1 \mathrm{~Hz}, J\left(\mathrm{~A}_{5}, \mathrm{~A}_{6}\right)=8.5 \mathrm{~Hz}, J\left(\mathrm{~A}_{5}, \mathrm{~A}_{6}\right)=3.0 \mathrm{~Hz}, \mathrm{H}-\mathrm{C}_{\mathrm{A}}(6)\right), 3.59(\mathrm{~m}, 1 \mathrm{H}, \mathrm{H}-$ $\left.\mathrm{C}_{\mathrm{A}}(6)\right), 1.92$ - $1.52\left(\mathrm{~m}, 6 \mathrm{H}, \mathrm{H}-\mathrm{C}_{\mathrm{A}}(3-5)\right) .{ }^{13} \mathrm{C}-\mathrm{NMR}\left(150 \mathrm{MHz}, \mathrm{CDCl}_{3}\right)$ : 136.7, 136.2, 130.6, 128.7, 128.6, 128.3, 99.0 (-OCHO-), 66.4, 62.3, 31.0, 30.5, 25.4 and 19.4. FT-IR (solid, cm1): 2939 (m), 2867 (w), 1723 (w), 1454 (m), 1385 (m),1260 (w), 1200 (m), 1118 (s), 1076 (m), 1022 (s), $971(\mathrm{~m}), 904(\mathrm{~m}), 869(\mathrm{~m}), 814(\mathrm{w}), 760(\mathrm{~m}), 606(\mathrm{~m}), 533(\mathrm{w})$

\section{Ethyl 2-\{3-oxo-2-\{2-\{[(tetrahydro-2H-pyran-2-yl)oxy]methyl\}benzyl\}-2,3-dihydro- $5 H-[1,2,4]$ triazino[5,6-b]indol-5-yl\}acetate $(12)$}

To a solution of $200.0 \mathrm{mg}(0.74 \mathrm{mmol}, 1.00 \mathrm{~mol} \mathrm{eq}) 2$ in $5 \mathrm{ml}$ DMF (abs), $37.0 \mathrm{mg}$ (0.88 mmol, $1.19 \mathrm{~mol} \mathrm{eq})$ of $\mathrm{CaH}_{2}$ was added and the mixture stirred at $80{ }^{\circ} \mathrm{C}$ under Ar within 30 $\mathrm{min}$. Then, the reaction was cooled to $\mathrm{rt}, 310 \mathrm{mg}(1.09 \mathrm{mmol}, 1.47 \mathrm{~mol} \mathrm{eq})$ of tetrahydropyran 11 was added dropwise and the solution was stirred at $80{ }^{\circ} \mathrm{C}$ within $1 \mathrm{~h}$ under Ar. After consumption of 2 (confirmed by a TLC analysis) the reaction was cooled down, $10 \mathrm{ml}$ of water added, and the mixture stirred for $10 \mathrm{~min}$ in an ice bath. Resulting mixture was extracted with DCM (3 x $15 \mathrm{ml})$, washed with brine $(3 \times 20 \mathrm{ml})$, dried over $\mathrm{Na}_{2} \mathrm{SO}_{4}$, filtered and concentrated under reduced pressure. A crude product was purified by $\mathrm{FLC}\left(\mathrm{SiO}_{2}, \mathrm{Hex} /\right.$ $\mathrm{EA}=1 / 5)$ to give $286 \mathrm{mg}(0.60 \mathrm{mmol}, 82 \%)$ of 12 as red oil. Novelty: ethyl 2-\{3-oxo-2-\{2$\{[$ (tetrahydro-2H-pyran-2-yl)oxy]methyl $\}$ benzyl $\}$-2,3-dihydro-5H-[1,2,4]triazino[5,6-b]indol5-yl \}acetate (12) has not been described in the literature.

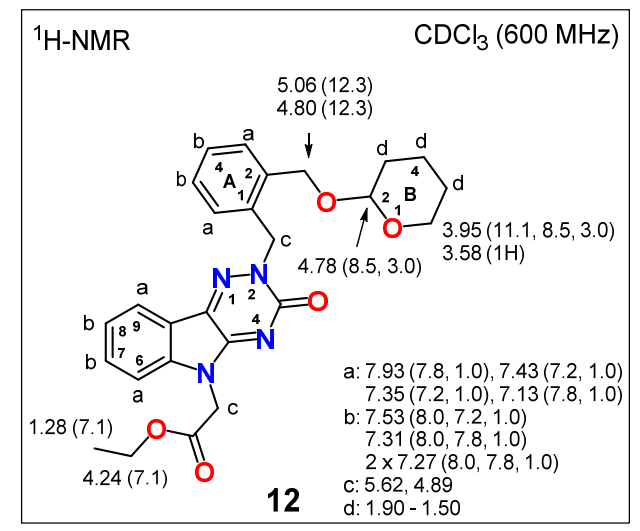

${ }^{1} \mathrm{H}-\mathrm{NMR}\left(600 \mathrm{MHz}, \mathrm{CDCl}_{3}\right): \delta 7.93,7.43,7.35$ and $7.13(4 \mathrm{x} \mathrm{dd}, 4 \mathrm{x} 1 \mathrm{H}, J(6,7$ or 8,9 or $\mathrm{A}_{3}, \mathrm{~A}_{4}$ or $\left.\mathrm{A}_{5}, \mathrm{~A}_{6}\right)=7.8$ and $7.2 \mathrm{~Hz}, J\left(6,8\right.$ or 7,9 or $\mathrm{A}_{3}, \mathrm{~A}_{5}$ or $\left.\mathrm{A}_{4}, \mathrm{~A}_{6}\right)=1.0 \mathrm{~Hz}, \mathrm{H}-\mathrm{C}\left(6,9, \mathrm{~A}_{3}\right.$ and A6)), 7.53, 7.31, $2 \times 7.27\left(4 \times \mathrm{ddd}, 4 \times 1 \mathrm{H}, J\left(7,8\right.\right.$ or $\left.\mathrm{A}_{4}, \mathrm{~A}_{5}\right)=8.0 \mathrm{~Hz}, J\left(6,7\right.$ or 8,9 or $\mathrm{A}_{3}, \mathrm{~A}_{4}$ or $\left.\mathrm{A}_{5}, \mathrm{~A}_{6}\right)=7.8$ and $7.2 \mathrm{~Hz}, J\left(6,8\right.$ or 7,9 or $\mathrm{A}_{3}, \mathrm{~A}_{5}$ or $\left.\mathrm{A}_{4}, \mathrm{~A}_{6}\right)=1.0 \mathrm{~Hz}, \mathrm{H}-\mathrm{C}\left(7,8, \mathrm{~A}_{4}\right.$ and $\left.\left.\mathrm{A}_{5}\right)\right), 5.06$ $\left(\mathrm{d}, 1 \mathrm{H}, J_{\mathrm{gem}}=12.3 \mathrm{~Hz},-\mathrm{OC} \underline{H}_{2} \mathrm{Ph}\right.$ ), 5.62 and 4.89 (surprisingly 2 x s, 2 x $2 \mathrm{H},-\underline{\mathrm{C}}_{2} \mathrm{COOEt}$ and $\left.-\underline{\mathrm{C}}_{2} \mathrm{Ph}\right), 4.80\left(\mathrm{~d}, 1 \mathrm{H}, J_{\mathrm{gem}}=12.3 \mathrm{~Hz},-\mathrm{OC}_{2} \mathrm{Ph}\right), 4.78\left(\mathrm{dd}, 1 \mathrm{H}, J\left(\mathrm{~B}_{2}, \mathrm{~B}_{3}\right)=8.5 \mathrm{~Hz}\right.$ and 
$\left.J\left(\mathrm{~B}_{2}, \mathrm{~B}_{3}\right)=3.0 \mathrm{~Hz}, \mathrm{H}-\mathrm{C}_{\mathrm{B}}(2)\right), 4.24\left(\mathrm{q}, 2 \mathrm{H}, J\left(\mathrm{CH}_{2}, \mathrm{CH}_{3}\right)=7.1 \mathrm{~Hz},-\mathrm{OCH}_{2} \mathrm{CH}_{3}\right), 3.95(\mathrm{ddd}, 1 \mathrm{H}$, $\left.J_{\mathrm{gem}}=11.1 \mathrm{~Hz}, J\left(\mathrm{~B}_{5}, \mathrm{~B}_{6}\right)=8.5 \mathrm{~Hz}, J\left(\mathrm{~B}_{5} \mathrm{~B}_{6}\right)=3.0 \mathrm{~Hz}, \mathrm{H}-\mathrm{C}_{\mathrm{B}}(6)\right), 3.58\left(\mathrm{~m}, 1 \mathrm{H}, \mathrm{H}-\mathrm{C}_{\mathrm{B}}(6)\right), 1.90-$ $1.50\left(\mathrm{~m}, 6 \mathrm{H}, 3 \mathrm{x}-\mathrm{CH}_{2}-\right.$ from $\left.\mathrm{C}\left(\mathrm{B}_{3}-\mathrm{B}_{5}\right)\right), 1.28\left(\mathrm{t}, 3 \mathrm{H}, J\left(\mathrm{CH}_{2}, \mathrm{CH}_{3}\right)=7.1 \mathrm{~Hz},-\mathrm{OCH}_{2} \mathrm{C}_{3}\right)$. Due to moisture instability of the $\mathbf{1 2}$, its other spectra and analysis were not recorded and compound 12 was used directly in the next step.

\section{2-\{2-[2-(Hydroxymethyl)benzyl]-3-oxo-2,3-dihydro-5H-[1,2,4]triazino[5,6-b]indol-}

\section{5-yl\}acetic acid 13 (OTI-10)}

To a solution of $50.0 \mathrm{mg}(0.11 \mathrm{mmol}, 1.00 \mathrm{~mol} \mathrm{eq})$ ester $12 \mathrm{in} 10 \mathrm{ml}$ of dioxane, $1 \mathrm{ml}$ of $\mathrm{H}_{2} \mathrm{O}$ and $0.1 \mathrm{ml}$ of $\mathrm{HCl}(37 \% \mathrm{w} / \mathrm{w})$ were added and resulting solution stirred at $90{ }^{\circ} \mathrm{C}$ for $8 \mathrm{~h}$. After that, TLC analysis confirmed presence of a new product without side products. Reaction mixture was cooled down, $30 \mathrm{ml}$ of water added and extracted with DCM (3 x $15 \mathrm{ml})$. Combined organic layer was dried over $\mathrm{Na}_{2} \mathrm{SO}_{4}$, filtered and concentrated under reduce pressure yielding $25.0 \mathrm{mg}(0.07 \mathrm{mmol}, 66 \%)$ of acid 13 (OTI-10) as a yellow solid compound. Novelty: 2-\{2-[2-(hydroxymethyl)benzyl]-3-oxo-2,3-dihydro-5H-[1,2,4]triazino[5,6-b]indol-5yl $\}$ acetic acid 13 (OTI-10) has not been described in the literature. M.p.: $220.0-238.0^{\circ} \mathrm{C}$ (dec) $[\mathrm{DCM}]$.

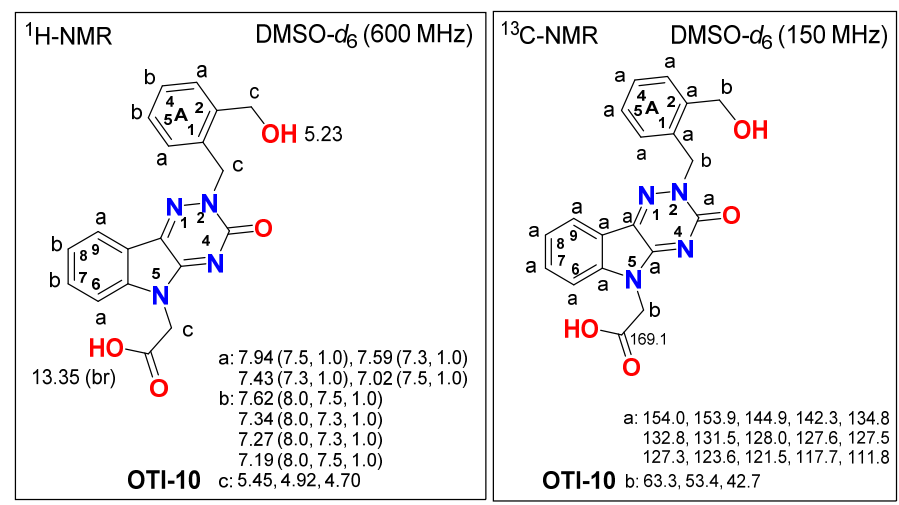

${ }^{1} \mathrm{H}-\mathrm{NMR}\left(600 \mathrm{MHz}, \mathrm{DMSO}-d_{6}\right): \delta 13.35$ (br s, $\left.1 \mathrm{H},-\mathrm{COOH}\right), 7.94,7.59,7.43$ and $7.02(4 \mathrm{x} \mathrm{dd}$, $4 \times 1 \mathrm{H}, J\left(6,7\right.$ or 8,9 or $\mathrm{A}_{3}, \mathrm{~A}_{4}$ or $\left.\mathrm{A}_{5}, \mathrm{~A}_{6}\right)=7.5$ or $7.3 \mathrm{~Hz}, J\left(6,8\right.$ or 7,9 or $\mathrm{A}_{3}, \mathrm{~A}_{5}$ or $\left.\mathrm{A}_{4}, \mathrm{~A}_{6}\right)=1.0$ $\mathrm{Hz}, \mathrm{H}-\mathrm{C}\left(6,9, \mathrm{~A}_{3}\right.$ and $\left.\left.\mathrm{A}_{6}\right)\right), 7.62,7.34,7.27$ and 7.19 (4 x ddd, 4 x 1H, $J\left(7,8\right.$ or $\left.\mathrm{A}_{4}, \mathrm{~A}_{5}\right)=8.0 \mathrm{~Hz}$, $J\left(6,7\right.$ or 8,9 or $\mathrm{A}_{3}, \mathrm{~A}_{4}$ or $\left.\mathrm{A}_{5}, \mathrm{~A}_{6}\right)=7.5$ or $7.3 \mathrm{~Hz}, J\left(6,8\right.$ or 7,9 or $\mathrm{A}_{3}, \mathrm{~A}_{5}$ or $\left.\mathrm{A}_{4}, \mathrm{~A}_{6}\right)=1.0 \mathrm{~Hz}, \mathrm{H}-$ $\mathrm{C}\left(7,8, \mathrm{~A}_{4}\right.$ and $\left.\left.\mathrm{A}_{5}\right)\right), 5.45,4.92$ and $4.70\left(3 \mathrm{x} \mathrm{s}, 3 \times 2 \mathrm{H},-\underline{\mathrm{C}}_{2} \mathrm{COOEt},-\underline{\mathrm{H}}_{2} \mathrm{Ph}\right.$ and $\left.-\underline{\mathrm{H}}_{2} \mathrm{OH}\right)$, $5.23(\mathrm{~s}, 1 \mathrm{H},-\mathrm{OH}) .{ }^{13} \mathrm{C}-\mathrm{NMR}\left(150 \mathrm{MHz}, \mathrm{DMSO}-d_{6}\right): 169.1$ (-COOH), 154.0, 153.9, 144.9, $142.3,134.8,132.8,131.5,128.0,127.6,127.5,127.3,123.6,121.5,117.7,111.8,63.3,53.4$ and 42.7. FT-IR (solid, $\mathrm{cm}^{-1}$ ): 3207 (w), 2922 (w), 2712 (w), 2602 (w), 2522 (w), 2108 (w), 2087 (w), 1728 (s), 1606 (s), 1577 (s), 1502 (m), 1467 (m), 1414 (s), 1374 (m), 1228 (s), 1203 
(s), $1116(\mathrm{w}), 1087(\mathrm{w}), 1045(\mathrm{~m}), 997(\mathrm{w}), 954(\mathrm{w}), 937(\mathrm{w}), 893(\mathrm{w}), 786(\mathrm{~m}), 751(\mathrm{~s}), 670$ (m), 610 (m), 585 (m), 478 (w), 434 (s). MS (ESI m/z): 363.0 (95\%) [M-H $\left.\mathrm{H}^{+}\right], 319.1$ (95\%) [M-CO $-\mathrm{CO}_{2}{ }^{+}$]. Anal. calcd for $\mathrm{C}_{19} \mathrm{H}_{16} \mathrm{~N}_{4} \mathrm{O}_{4}$ (364.36): C, 62.63; H, 4.43; N, 15.38 Found: C, $62.75 ; \mathrm{H}, 4.49 ; \mathrm{N}, 15.55$.

Animals: Male Wistar rats 8 - 9 weeks old, weighing 200 - $230 \mathrm{~g}$, were used as organ donors. The animals came from the Breeding Facility of the Institute of Experimental Pharmacology Dobrá Voda (Slovak Republic). The study was approved by the Ethics Committee of the Institute and performed in accordance with the Principles of Laboratory Animal Care (NIH publication 83 - 25, revised 1985) and the Slovak law regulating animal experiments (Decree 289, Part 139, July $\left.9^{\text {th }} 2003\right)$.

Enzyme assays: Preparation of ALR2 from the rat lens and ALR1 from the rat kidneys was previously reported. ${ }^{25}$ Enzyme activities were assayed spectrophotometrically by determining NADPH consumption at $340 \mathrm{~nm}$ and were expressed as decrease of the optical density (O.D.) / $\mathrm{s} / \mathrm{mg}$ protein. ${ }^{25}$ The experimental procedures are in detail described in Supporting information to this paper.

\section{Acknowledgements}

$\mathrm{MH}$ and $\mathrm{AB}$ equally contributed to writing of this paper. This research was supported by Biomagi, Ltd. (design of novel OTI inhibitors) and by VEGA 1/0670/18 project (synthesis). Our gratitude belongs to LK, MSP and MS for biological assays and evaluation of a biological activity supported by VEGA 2/0005/2018. MH, GH contributed to the development of synthesis and AG to analysis of prepared compounds. We are grateful to Mgr. Juraj Filo, $\mathrm{PhD}$, for the measurement of NMR spectra and Bc. Lenka Soboličová for synthesis of intermediates and the inhibitor OTI-7. Finally, we would like to thank bilateral project APVV SK-FR-2015-0014 and COST Action CA15135 MuTaLig for networking and Cotutelle joint $\mathrm{PhD}$ French-Slovak program for $\mathrm{MH}$ bilateral study.

\section{Appendix A. Supplementary data}

Supplementary data associated with this article can be found in the online version, at http://xxx. These data include spectra of compounds described in this article together with predicted poses and interaction analyses for all developed inhibitors. Included are also 
experimental procedures comprising isolation of rat kidney ALR1, rat eye lens ALR2 and enzyme activity assays.

\section{References}

1. Schrijvers, B.F.; De Vriese, A.S.; Flyvbjerg, A. From hyperglycemia to diabetic kidney disease: the role of metabolic, hemodynamic, intracellular factors and growth factors/cytokines. Endocr. Rev., 2005, 25, 971 - 1010. Doi: 10.1210/er.2003-0018.

2. Brownlee, M. Biochemistry and molecular cell biology of diabetic complications. Nature, 2001, 414, 813 - 820. Doi: 10.1038/414813a.

3. Vistoli, G.; De Maddis, D.; Cipak, A.; Zarkovic, N.; Carini, M.; Aldini, G. Advanced glycoxidation and lipoxidation end products (AGEs and ALEs): an overview of their mechanisms of formation. Free Radic. Res., 2013, 47, 3 - 27. Doi: $10.3109 / 10715762.2013 .815348$.

4. Kyselova, Z.; Stefek, M.; Bauer, V. Pharmacological prevention of diabetic cataract. J. Diabetes Complicat., 2004, 18, 129 - 140. Doi: 10.1016/S1056-8727(03)00009-6.

5. Alexiou, P.; Pegklidou, K.; Chatzopoulou, M.; Nicolaou, I.; Demopoulos, V.J. Aldose reductase enzyme and its implication to major health problems of the 21 (st) century. Curr. Med. Chem., 2009, 16, 734 - 752. Doi: 10.2174/092986709787458362.

6. Srivastava, S.K.; Yadav, U.C.; Reddy, A.B.; Saxena, A.; Tammali, R.; Shoeb, M.; Ansari, N.H.; Bhatnagar, A.; Petrash, M.J., Srivastava, S.; Ramana, K.V. Aldose Reductase Inhibition Suppresses Oxidative Stress-Induced Inflammatory Disorders. Chem. Biol. Interaction, 2011, 191, 330 - 338. Doi: 10.1016/j.cbi.2011.02.023.

7. Maccari, R.; Ottanà, R. Targeting aldose reductase for the treatment of diabetes complications and inflammatory diseases: new insights and future directions. J. Med. Chem., 2015, 58, 2047 - 2067. Doi: 10.1021/jm500907a.

8. Grewal, A.S.; Bhardwaj, S.; Pandita, D.; Lather, V.; Sekhon, B.S. Updates on Aldose Reductase Inhibitors for Management of Diabetic Complications and Non-diabetic Diseases. Mini. Rev. Med. Chem., 2016, 16, 120 - 162. Doi: $10.2174 / 1389557515666150909143737$.

9. Ballekova, J.; Soltesova-Prnova, M.; Majekova, M.; Stefek, M. Does Inhibition of Aldose Reductase Contribute to the Anti-Inflammatory Action of Setipiprant? Physiol. Res., 2017, 66, 687 - 693. doi: 10.33549/physiolres.933516. 
10. Morava, E. Elevated sorbitol underlies a heritable neuropathy. Nat. Genet., 2020, 52, 469 470.

11. Vyas, B.; Choudhary, S.; Singh, P.K.; Kumar, M.; Verma, H.; Singh, M.; Malik, A.K.; Silakari, O. Search for non-acidic ALR2 inhibitors: Evaluation of flavones as targeted agents for the management of diabetic complications. Bioorg. Chem., 2020, 96, article 103570. Doi: 10.1016/j.bioorg.2020.103570.

12. Stefek, M.; Soltesova Prnova, M.; Majekova, M.; Rechlin, C.; Heine, A.; Klebe, G. Identification of Novel Aldose Reductase Inhibitors Based on Carboxymethylated Mercaptotriazinoindole Scaffold. J. Med. Chem., 2015, 58, 2649 - 2657. Doi: 10.1021/jm5015814.

13. Hlaváč, M.; Kováčiková, L.; Šoltésová Prnová, M.; Šramel, P.; Addová, G.; Májeková, M.; Hanquet, G.; Boháč, A.; Štefek, M. Development of Novel Oxotriazinoindole Inhibitors of Aldose Reductase: Isosteric Sulfur / Oxygen Replacement in the Thioxotriazinoindole Cemtirestat Markedly Improved Inhibition Selectivity J. Med. Chem., 2020, 63, 369 - 381. Doi:10.1021/acs.jmedchem.9b01747.

14. Dobiáš, J.; Ondruš, M.; Hlaváč, M.; Murár, M.; Kóňa, J.; Addová, G.; Boháč, A. Medicinal chemistry: an efect of a desolvation penalty of an amide group in the development of kinase inhibitors Chem. Papers, 2019, 73, 71 - 84. Doi: 10.1007/s11696-018-0576-6.

15. Hopkins, A.L.; Keserü, G.M.; Leeson, P.D.; Rees, D.C.; Reynolds, C.H. The role of ligand efficiency metrics in drug discovery. Nat. Rev. Drug Discov. 2014, 13, 105- 121. Doi: $10.1038 / \mathrm{nrd} 4163$.

16. Keserü, G.M.; Makara, G.M. The Influence of Lead Discovery Strategies on the Properties of Drug Candidates. Nat. Rev. Drug Discov. 2009, 8, 203 - 212. Doi: 10.1038/nrd2796.

17. Perola, E. An Analysis of the Binding Efficiencies of Drugs and their Leads in Successful Drug Discovery Programs. J. Med. Chem. 2010, 53, 2986 - 2997. Doi: 10.1021/jm100118x.

18. Irwin, J.J.; Shoichet, B.K.; Mysinger, M.M.; Huang, N.; Colizzi, F.; Wassam, P.; Cao, Y.; Automated docking screens: a feasibility study J. Med. Chem., 2009, 52, 5712 - 5720. Doi: $10.1021 / \mathrm{jm} 9006966$.

19. https://discover.3ds.com/discovery-studio-visualizer-download

20. https://www.schrodinger.com/maestro

21. Dow, M.; Marchetti, F.; Abrahams, K.A.; Vaz, L.; Besra, G.S.; Warriner, S.; Nelson, A. Modular Synthesis of Diverse Natural Product-Like Macrocycles: Discovery of Hits with 
Antimycobacterial Activity. Chem.: Eur. J., 2017, 23, 7207 - 7211. Doi: 10.1002/chem.201701150.

22. Cowell, A.; Stille, J.K. Synthesis of lactones by the palladium-catalyzed carbonylation of halo alcohols J. Am. Chem. Soc., 1980, 102, 4193 - 4198. Doi: 10.1021/ja00532a034.

23. Doyle, M.P.; Chapman, B.J.; Hu, W.; Peterson, C.S. Catalytic Intramolecular Addition of Metal Carbenes to Remote Furans Org. Lett., 1999, 1, 1327 - 1329. Doi: $10.1021 / \mathrm{ol} 990168 \mathrm{t}$.

24. Novartis AG; Novartis Pharma GMBH; Masuya, Keiichi - WO2006/74924, 2006, A1.

25. Stefek, M.; Snirc, V.; Djoubissie, P.O.; Majekova, M.; Demopoulos, V.; Rackova, L.; Bezakova, Z.; Karasu, C.; Carbone, V.; El-Kabbani, O. Carboxymethylated pyridoindole antioxidants as aldose reductase inhibitors: synthesis, activity, partitioning, and molecular modeling. Bioorg Med Chem., 2008, 16, 4908 - 4920. Doi: 10.1016/j.bmc.2008.03.039.

26. Majekova, M.; Ballekova, J.; Prnova, M.; Stefek, M. Structure Optimization of Tetrahydropyridoindole-Based Aldose Reductase Inhibitors Improved their Efficacy and Selectivity. Bioorg. Med. Chem. 2017, 25, 6353 - 6360. Doi: 10.1016/j.bmc.2017.10.005. 